Review

\title{
Green Synthesis of Gold, Silver, and Iron Nanoparticles for the Degradation of Organic Pollutants in Wastewater
}

\author{
Brajesh Kumar iD
}

Citation: Kumar, B. Green Synthesis of Gold, Silver, and Iron Nanoparticles for the Degradation of Organic Pollutants in Wastewater. J. Compos. Sci. 2021, 5, 219. https://doi.org/ $10.3390 /$ jcs5080219

Academic Editor: Pankaj Attri

Received: 6 April 2021

Accepted: 30 July 2021

Published: 16 August 2021

Publisher's Note: MDPI stays neutral with regard to jurisdictional claims in published maps and institutional affiliations.

Copyright: (C) 2021 by the author. Licensee MDPI, Basel, Switzerland. This article is an open access article distributed under the terms and conditions of the Creative Commons Attribution (CC BY) license (https:// creativecommons.org/licenses/by/ $4.0 /)$.
Post Graduate Department of Chemistry, TATA College, Kolhan University, Chaibasa 833202, India; krmbraj@gmail.com or krmbrajnano@gmail.com; Tel.: +91-8757618562

\begin{abstract}
The green synthesis of nanoscale materials is of special interest to researchers all over the world. We describe a simple, robust, inexpensive, and environmentally friendly approach to the synthesis of gold, silver, and iron nanoparticles using a variety of biomolecules/phytochemicals as potential reducers and stabilizers. The green approach to the controlled synthesis of nanoparticles with different morphologies is based on the use of plant extracts. Green synthesized nanoparticles can be used as catalysts, photocatalysts, adsorbents, or alternative agents for the elimination of various organic dyes. The kinetic enhancement of nanoparticles for the degradation/removal of dyes could provide significant and valuable insights for the application of biochemically functionalized nanoparticles in engineering. In this review, current plant-mediated strategies for preparing nanoparticles of gold, silver, and iron are briefly described, and morphologically dependent nanoparticles for the degradation of organic pollutants in wastewater are highlighted. Overall, the approach presented in the article supports environmental protection and is a promising alternative to other synthesis techniques.
\end{abstract}

Keywords: green synthesis; nanoparticles; UV-Vis spectroscopy; photocatalyst; wastewater treatment

\section{Introduction}

Currently, nanotechnology is one of the most promising research fields regarding the development of nanomaterials and especially nanoparticles (NPs) ranging from 1 to $100 \mathrm{~nm}$ in size. It has been the center of attention due to the synthesis of nanoparticles of various materials to be used in different sectors thanks to their unique physical and chemical properties when compared to the corresponding bulk materials. These distinctive properties, related to the high surface to volume ratio of nanoparticles or quantum effects, have attracted notable interest from chemists, biologists, physicists, and engineers [1]. In the past decade, the synthesis of engineered nanoparticles including metals, metal oxides, non-metals, lipids, and polymers, as well as various nanocomposites, has attracted increasing interest for various applications, in emerging technologies and in consumer products such as optical, electrical, and catalytic devices, sensors, electronic devices, and other products used for personal care, biomedicine, antibacterial purposes, agriculture, renewable energy, water and soil treatment, etc. [2,3]. Inorganic nanoparticles, especially those that are purely made from gold, silver, copper, etc., have unique optical and photothermal properties due to their well-known localized surface plasmon resonance (LSPR) and their broad absorption spectrum in the visible region of electromagnetic radiation. Gold and silver nanoparticles have enhanced optoelectronic properties, stability, and biocompatibility. Therefore, they have been used in products within different industrial fields, such as medicine, food, biomaterials, sensing, dye-sensitized solar cells, catalysis, and photocatalysis [4].

In the last few decades, a great deal of research on nanoparticle synthesis has emphasized their use in biological procedures and applications in the engineering and biomedical fields. Bottom-up approaches are preferred over top-down approaches for the fabrication 
of nanoparticles, and it can be carried out through physical, chemical, and bio-assisted methods. Surface-modified metal nanoparticles can be synthesized by the reduction of metal ions followed by the capping or surface functionalization of nanoparticles; agents such as gallic acid, citric acid, polyphenols, starch, polysaccharides, proteins, terpenoids, saponins, surfactants, and polymers have been used to enhance the stability of nanoparticles [5]. The stability of the surfaces of organically capped metal nanoparticles could be influenced differently by environmental conditions such as temperature, $\mathrm{pH}$, humidity, the presence of interfering ions, and light when compared to the typical inert conditions for nanoparticles [1].

To date, various popular physical and chemical methods have been involved in nanoparticle synthesis, including solution-phase synthesis, chemical reduction, the sol-gel technique, evaporation-condensation, hydrothermal synthesis, the wet chemical method, sonochemical synthesis, the microwave method, the laser ablation method, and ball milling [6], in which a large amount of solvent is required in order to obtain pure and well-defined nanoparticles. However, these methods are costly and also create various problems for the ecosystem and the environment. To overcome these issues, safe, inexpensive, environmentally friendly, green methods that can be easily scaled up for the large-scale production of nanoparticles are recommended using various plant materials/biomolecules due to the generation of environmentally benign products and byproducts after the completion of nanoparticle synthesis [7]. Furthermore, these methods do not require harsh conditions such as high temperature, pressure, and energy or the use of toxic chemicals (Figure 1). Therefore, various natural materials adopted for the biosynthesis of nanoand micro-scaled inorganic materials having different compositions, sizes, shapes, and controlled dispersity are needed; this remains an unexplored area of nanotechnology research but is recommended due to the potential benefits of simplicity and sustainability [8]. Extracts of plants or their parts, such as roots, leaves, fruits, flowers, bark, and seeds, have been extensively screened for their ability to promote the biosynthesis of different kinds of metallic NPs, oxide NPs, and chalcogenide NPs [9].

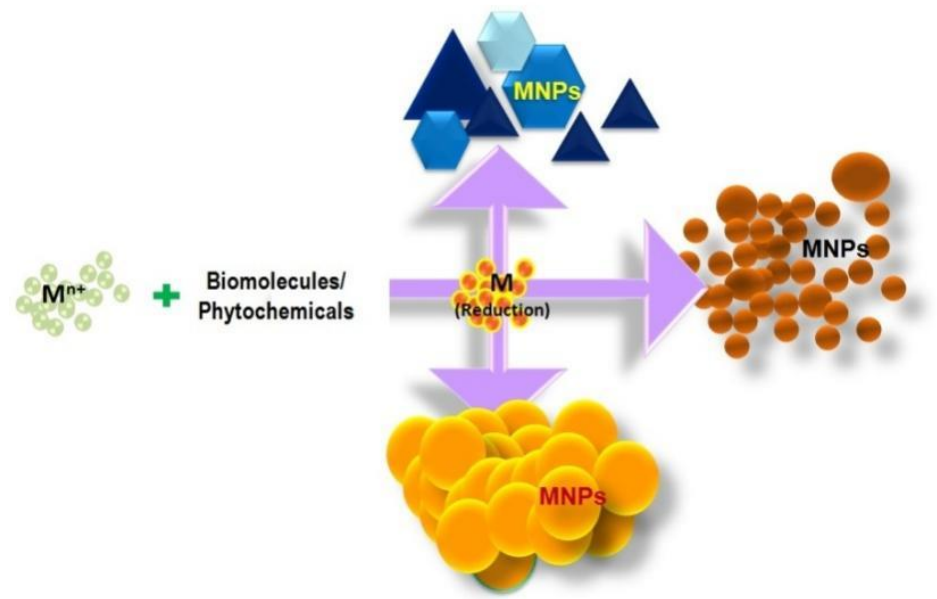

Figure 1. Schematic representation for the biosynthesis of different morphological metal nanoparticles.

The increased popularity of research on gold (Au), silver (Ag), and various types of iron/iron oxide (Fe/FeO-NPs) nanoparticles in the past several decades has attracted much attention due to the ease of synthesis via the use of safe, green methods involving biomolecules and phytochemicals; these can be further used in a wide variety of engineering and biomedical applications. As a result of the large specific surface areas of $\mathrm{Ag}, \mathrm{Au}$, and $\mathrm{Fe} / \mathrm{FeO}-\mathrm{NPs}$, the large band gap, and the reactive surfaces of iron oxide nanoparticles, they could be a good choice for the photocatalysis and adsorption of various synthetic dyes [10].

In recent decades, wastewater or effluent containing non-biodegradable dyes and organic pollutants from various industries, factories, and laboratories have been discharged 
into water reservoirs without any treatment, and it poses a growing global environmental hazard [11]. In general, chromophores and auxochromes are both key components of organic dyes: chromophores are the main coloring group that is responsible for producing the color variety in the visible region due to delocalized electron systems with conjugated double bonds $\left(n \rightarrow \pi^{*}\right.$ and $\pi \rightarrow \pi^{*}$ ), whereas auxochromes are responsible for intensifying the color of the chromophore. They are usually electron-donar or electron-withdrawal substituents that enhance the color intensity by altering the overall energy of the electronic systems. The usual chromophores are $-\mathrm{C}=\mathrm{C}-,-\mathrm{C}=\mathrm{N}-,-\mathrm{C}=\mathrm{O},-\mathrm{N}=\mathrm{N}-,-\mathrm{NO}_{2}$, and the quinoid rings, whereas the auxochromes are $-\mathrm{NH}_{3},-\mathrm{COOH},-\mathrm{SO}_{3} \mathrm{H}$, and $-\mathrm{OH}$ groups. Different groups of dyes can be distinguished and easily identified according to the chemical or chromophore structure. The generic name of the color index (CI) of each different organic dye is given to determine its application characteristics and its color [12]. These dyes are widely used in large quantities in many industries for various applications such as textiles, papers, leathers, foodstuffs, cosmetics, laser materials, xerography, laser printing, gasoline, additives, etc. In most cases, byproducts discarded from industries contain dyes and heavy metal ions, or both [13]. It is estimated that over $15 \%$ of the total worldwide production of dyes is lost in their synthesis and dyeing process [14]. Most of these anthropogenic dyes are toxic, carcinogenic, and reduce the light penetration into aqueous systems. Consequently, it causes serious concern to society because of its complex structures and non-biodegradable nature, which has a negative effect on photosynthesis, is toxic for living organisms, is harmful to human health, and contributes significantly to the overall imbalance of the ecosystem [15].

Wastewater with high concentrations of biodegradable pollutants could be treated using biological treatment methods. However, wastewater from many industries such as pharmaceuticals, textiles, and agriculture often contains toxic pollutants with low biodegradability [16]. Photocatalysis is an environment friendly, sustainable, and energysaving technique that has proven to be a promising alternative for the degradation of many organic pollutants. Photocatalysis in the water treatment process is based on the advanced oxidation process, which has progressed rapidly since Fujishima and Honda discovered the photoelectrochemical water splitting reaction using a semiconductor in 1972 [17]. Photocatalysts are responsible for exploiting solar energy to degrade pollutants that make the photocatalysis treatment process economically viable [18]. Although most research has worked on synthetic or model solutions, research on real industrial wastewater or surface water is very limited.

The contents of this review article can be briefly focused on the latest breakthroughs in green production of gold, silver, and iron/iron oxide nanoparticles using different plant materials/biomolecules and their instrumental characterization. Furthermore, special attention is given to the possible use of nanoparticles for the degradation/remediation of organic pollutants in wastewater (Figure 2) and may open new avenues for the development of nanoscience and nanotechnology in agroindustry.

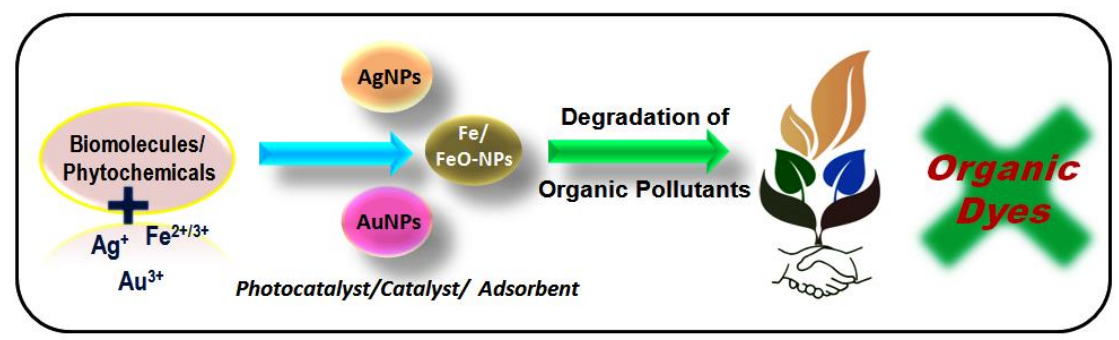

Figure 2. Schematic diagram of the biosynthesis of gold, silver, and iron/iron oxide nanoparticles for the degradation of organic pollutants.

Numerous studies have been conducted, and widely reviewed papers are available on the synthetic procedures of gold, silver, and iron nanoparticles. Here, we briefly report an update of the discussion on their existing green synthetic approaches using different 
plant materials (Figure 3), large-scale fabrication, and their remediation techniques. Then, it is followed by a description of their optical, morphological, spectroscopic, crystalline structures, and catalytic properties.

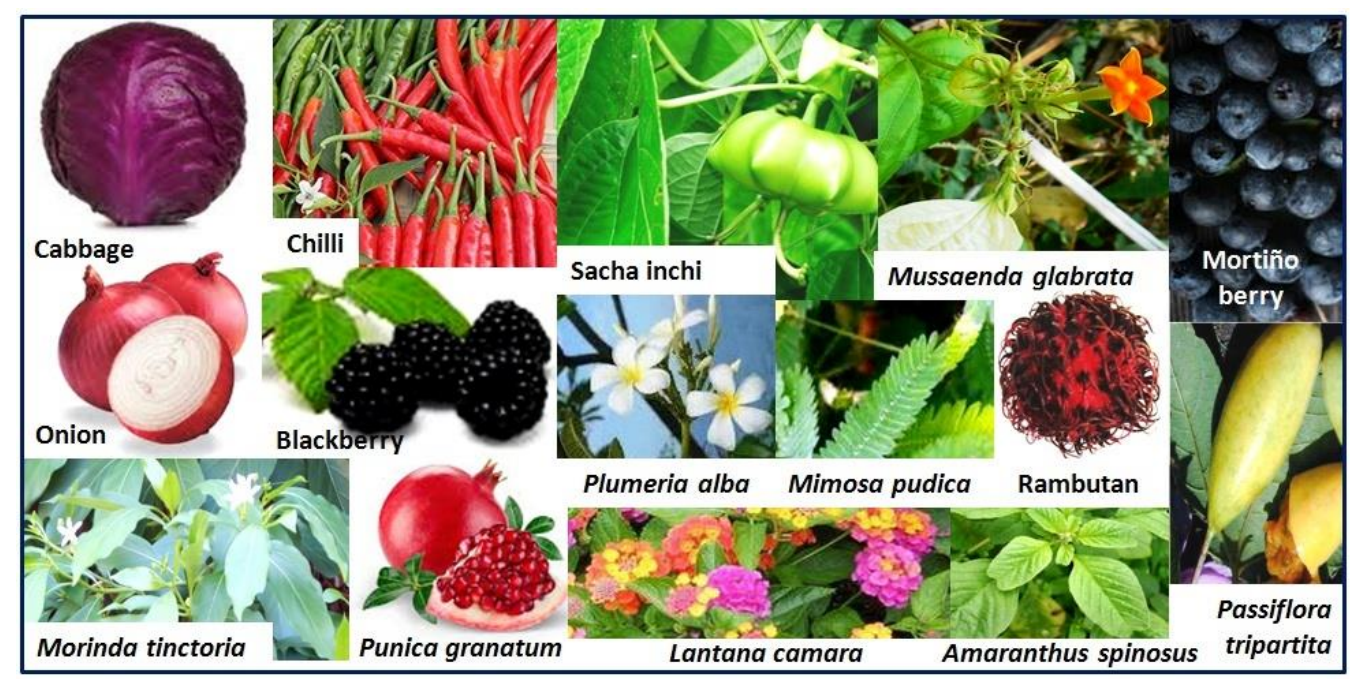

Figure 3. A variety of plant materials used for the biosynthesis of gold, silver, and iron/iron oxide nanoparticles for the removal of different organic dyes.

\section{Surface Plasmon Resonance}

More than 100 years ago, R.W. Wood first reported the phenomenon of the surface plasmon resonance (SPR) in 1902 [19], where he observed a form of abnormal incident, angle-dependent bands on a metal-supported diffraction grating shed by polarized light. His concept of the SPR phenomenon has been extensively explained and elaborated by many researchers from their work. To date, numerous scientific fields have taken advantage of the SPR either directly or indirectly from simple optical detection techniques to solar energy conversion technology [20]. In addition to extensive and intensive research work on SPR, its sub-area, localized surface plasmon resonance (LSPR), has also attracted a lot of attention to the development of nanotechnologies [21]. The dipole plasmon mode, the quadrupole mode, and the significantly advanced plasmon mode are fundamental plasmonic resonances responsible for the LSPR of the plasmonic NPs.

Among these, the dipolar plasmon resonance is the most relevant factor responsible for the photocatalytic applications. This occurs due to the coherent oscillation of surface conduction electrons in plasmonic nanoparticles upon excitation by electromagnetic radiation at the interfaces between metal and dielectric media. LSPR usually occurs when plasmonic nanoparticles are significantly smaller than the wavelength of the incident light. The LSPR wavelength and absorption efficiency can simply be altered by changing the sizes, shapes, compositions, and dielectric environments of the plasmonic NPs [22]. The dimensions of the nanostructures allow the plasmon to oscillate locally, inside the nearby metal surface. Under light irradiation, the electric field is displaced by conduction electrons qualified for nuclei, prompting a large electric dipole. At the same time, a restoring force arises as a result of the Coulomb attraction between the electrons and nuclei. The result is a resonanting oscillation of the conduction electrons at a certain frequency. The LSPR characteristics may lead to various mechanisms of energy transfer from the plasmonic NPs to the metallic oxide semiconductors. Moreover, they offer versatile means to enhance the efficiency of each energy transfer progression [23]. LSPR and plasmonic nanoparticles can provide a couple of advantages over traditional SPR. Firstly, the LSPR measurement platform does not need a prism, and the angle of incident light is not as important as in the SPR platform; this means that the design of a plasmonic device can be much more affordable and flexible, and it is not susceptible to vibration or mechanical noise. The LSPR shows relatively less sensitivity to bulk refractive index changes compared to the SPR 
due to the short range of the enhanced electromagnetic field, so more focused studies on reactions or sites of interest are available without much interference from bulk solvent [22].

There are multiple reasons for the dominance of gold and silver nanoparticles in plasmonic nanoparticles research due to its chemical inertness, oxidation free, and high biocompatibility, which is crucial for biomedical applications [24]. It can be easily tuned to absorb and scatter light throughout the visible and near-infrared regions (LSPRs 300 to $1200 \mathrm{~nm}$ ). Figure 4 shows the typical visual image of the SPR, the UV-visible spectra, and transmission electron microscope image of as-synthesized gold nanoparticles using Persea americana (Avocado) oil. It clearly confirmed that LSPR depends on the composition and morphology of the nanoparticles and other surrounding factors. The formation of magenta/pinkish purple in the gold solution supports the reduction from $\mathrm{Au}^{3+}$ to $\mathrm{Au}^{0}$, and this was confirmed by the appearance of a single surface SPR absorption peak at $520 \mathrm{~nm}$ using a UV-visible spectrophotometer, corresponding to the spherical shape and the absorption spectrum of the nanoparticles recorded between 300 and1100 nm in direct sunlight for $120 \mathrm{~min}$. In contrast, the presence of a weak band above $1000 \mathrm{~nm}$ indicates the formation of triangular gold nanoparticles. As-synthesized gold nanoparticles were stable for two months without change in color and absorbance pattern. The TEM results of prepared gold nanoparticles using avocado oil under real sunlight irradiation were non-aggregated, well dispersed with an average size ranging from 20 to $100 \mathrm{~nm}$ in diameter (Figure 4), and also indicated the co-existence of spherical, quasi-spherical, decahedral, and triangular nanoparticles [25].

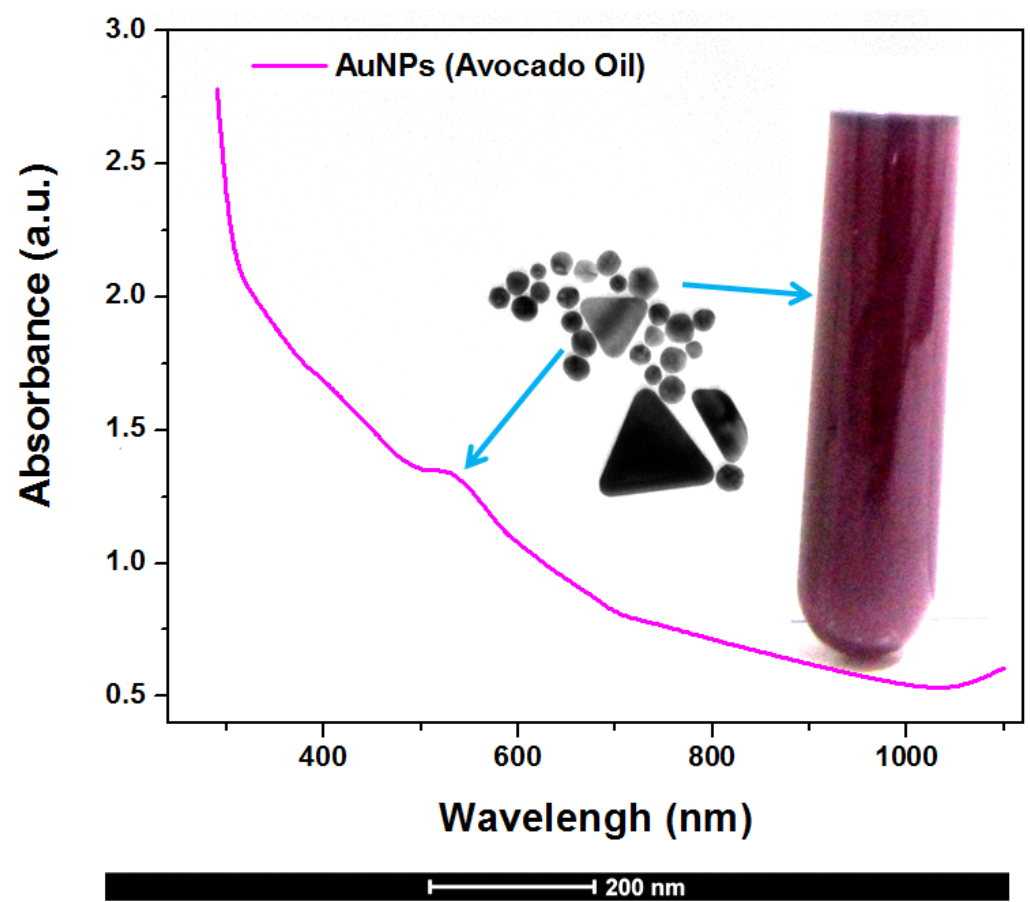

Figure 4. Visual, UV-visible, and transmission electron microscopy images of synthesized gold nanoparticles using avocado oil.

\section{Gold Nanoparticles}

These days, numerous research works have been done in connection with gold nanoparticles and have attracted increasing interest in their unique properties. It is notable that their morphology-dependent optical, chemical, and electronic properties offer promising applications in many areas, including catalysis [26]. It displays extensive UV light absorption, causing the transition of $5 \mathrm{~d}$ electrons to the $6 \mathrm{sp}$ band (interband electron transitions) and also its significantly enhanced catalytic activity [27]. Photocatalysis is an advanced solar light driven physicochemical technology applicable to the photodegradation of organic pollutants. Nowadays, the biosynthesis of gold nanoparticles appears to be 
a cost-effective and more promising alternative than chemical synthesis due to its ease of availability, simplicity, and eco-friendliness. Recently, extracellular biosynthesis methods employing various plant extracts, including Cinnamomum zeylanicum leaf, Zingibe rofficinale root, Aloe vera, Plukenetia volubilis oil, Rambutan peel, sugar beet pulp, edible mushroom, and Lantana camara berry have emerged as non-hazardous alternatives to chemical synthesis procedures for the bulk production of nanoparticles [28]. Table 1 presents the synthesis of gold nanoparticles using different plant extracts and its degradation efficiency. The general reaction involving the synthesis of gold nanoparticles using plant extract follows:

$$
\mathrm{Au}^{3+}+-\mathrm{CHO} /-\mathrm{OH} \rightarrow \mathrm{Au}^{0}+-\mathrm{COOH} / \mathrm{C}=\mathrm{O} .
$$

Kumar et al. (2018) synthesized multiple shapes of gold nanoparticles having an average size of $48.8 \pm 24.8 \mathrm{~nm}$ (Figure 4). FTIR analysis confirmed that unsaturated fatty acids, vitamin $\mathrm{E}$, vitamin $\mathrm{C}$, vitamin B6, $\beta$-carotene, and capped with carboxylic acid $(-\mathrm{COOH})$ groups of fatty acid in avocado oil were responsible for the synthesis of gold nanoparticles by reducing $\mathrm{Au}^{3+}$ to $\mathrm{Au}^{0}$. Prepared gold nanoparticles not only showed higher antioxidant activity $(\approx 30 \%)$ than avocado oil against 1,1-diphenyl-2-picrylhydrazyl but also proved considerable photocatalytic decomposition activity of the methylene blue $\left(>84 \%, 10 \mathrm{mg} / \mathrm{L}\right.$ ) with a rate constant $\mathrm{k}=0.0057664 \mathrm{~min}^{-1}$ in solar light [25]. Kumar et al. 2015 synthesized gold nanoparticles using Capsicum baccatum L. (Aji Amarillo/Chilli) fruit extracts and studied their photocatalytic activity against methylene blue dye. C. baccatum $\mathrm{L}$. is a traditional vegetable crop in Latin America including Ecuador, Peru, Argentina, Bolivia, Brazil, Chile, Costa Rica, Hawaii, and it is also cultivated in many countries around the world. The green-synthesized nanoparticles were spherical in shape with an average size of $23.9 \pm 9.7 \mathrm{~nm}$ and exhibited 50\% MB photodegradation after $5 \mathrm{~h}$ [29]. A study report by Paul et al. (2016) demonstrated that Parkia roxburghii leaf (dried biomass) mediated the synthesis of gold $(\mathrm{Au})$ and silver $(\mathrm{Ag})$ nanoparticles by the dried biomass of Parkia roxburghii leaf where the leaf biomass acts as both reducers as well as stabilizers. The specific UV-visible spectra of the synthesized AuNPs and AgNPs showed SPR at 555 and $440 \mathrm{~nm}$ after incubation for $12 \mathrm{~h}$. The TEM image showed that AuNPs were monodispersed, spherical in shape, with sizes in the range of 5-25 nm. On the other hand, the AgNPs were polydispersed and quasi-spherical in shape, with sizes ranging from 5 to $25 \mathrm{~nm}$. Investigation of the photocatalytic activities of Au and Ag NPs under solar light illumination reveals that both these particles have pronounced effect on the degradation of methylene blue and rhodamine $B$ dyes; the ' $k$ ' values with gold nanoparticles were found to be 0.263 and $0.209 \mathrm{~min}^{-1}$, whereas with AgNPs, they were found to be 0.188 and $0.174 \mathrm{~min}^{-1}$ [30].

Plants and their phytochemicals play an important role in the biosynthesis of nanoparticles mainly due to their easy availability and ecofriendly nature. Baruah et al. (2018) reported on a green technique using Alpinia nigra leaf extract for the synthesis of gold nanoparticles and evaluated their photocatalytic activities. The presence of flavonoid in A. nigra leaves is confirmed through High-Performance Liquid Chromatography (HPLC) analysis. The TEM micrographs showed that the average particle size of the nanoparticles was $21.52 \mathrm{~nm}$ and predominantly spherical, and it also showed very good photocatalytic degradation of methyl orange $(83.25 \%)$ and rhodamine B $(87.64 \%)$, respectively in the presence of direct sunlight [31]. In another investigation by Desai et al. (2018), green synthesis of photoluminescent gold nanoparticles using Kokum fruit (Garcinia indica Choissy) extract with enhanced catalytic and antioxidant activities was reported. The optimized condition for the biosynthesis of gold nanoparticles was 1:3 ratio of $0.6 \mathrm{mM} \mathrm{HAuCl}_{4}$ to extract at $\mathrm{pH} 4,80^{\circ} \mathrm{C}$ for $15 \mathrm{~min}$. The investigation confirmed that the photocatalytic activity of gold nanoparticles for the degradation of methylene violet dye in the presence of visible light $\left(89.17 \%, \mathrm{k}=0.014 \mathrm{~min}^{-1}\right)$ was slightly faster than UV light $\left(86.02 \%, \mathrm{k}=0.0025 \mathrm{~min}^{-1}\right)$ [32]. Kumar et al. (2016) investigated the morphology-controlled biosynthesis of gold nanoparticles by adding small amounts of L. camara flower extract. The UV-visible absorption spectra for the biosynthesized gold nanoparticles showed a single $\lambda_{\max }$ at $530 \mathrm{~nm}$ corresponding to a monodisperse and spherical nanogold of average size $10.6 \pm 2.9 \mathrm{~nm}$. The 
gold nanoparticles as prepared were non-aggregated and showed significant photocatalytic degradation activity against $\mathrm{MB}(>62 \%, 10 \mathrm{mg} / \mathrm{L})$ in the presence of sunlight. In addition, the experimental approach is fast, cheap, environmentally friendly, and can be used as an alternative agent for the removal of anthropogenic MB dye from waste water [33]. They also developed an ecofriendly methodology irradiated by sunlight to obtain gold nanoparticles using Sacha inchi oil. Sacha inchi (Plukentia volubilis L.) is a promising crop that originated from the Andes region, whose star-shaped seed oil has a bitter taste and is enriched with omega 3, 6, 9 fatty acids (35-60\%) and proteins (27\%). The spectroscopic and morphological properties of gold nanoparticles revealed the SPR peak at 515-520 nm with an average size of 5-15 $\mathrm{nm}$ and an almost spherical shape. The synthesized gold nanoparticles showed promising photocatalytic activity for the degradation of $\mathrm{MB}(>75 \%)$ under exposure to sunlight [34]. Mythili et al. (2018) utilized market vegetable waste for the biosynthesis of gold nanoparticles and substituted harmful chemicals by using the green method. Furthermore, the gold nanoparticles obtained from vegetable waste have been characterized by different microscopic and spectroscopic techniques. Spherical particle sizes ranged from 10 to70 $\mathrm{nm}$ with significant antibacterial activity against clinical microorganisms / pathogens [35]. Devi et al. (2015) reported an environmentally benign synthesis of gold nanoparticles in aqueous medium via Mimosa pudica leaves extract at room temperature. The synthesized particles were monodispersed and had a spherical shape, with an average diameter of $16 \mathrm{~nm}$. The ensuing gold nanoparticles were further used as an efficient nanocatalyst in aqueous medium for the degradation of rhodamine $B$ in the presence of $\mathrm{NaBH}_{4}$ at room temperature. In the presence of nanogold, the rate of reaction was abruptly enhanced by first-order kinetics with a catalytic efficacy of $\mathrm{k}=0.6319 \mathrm{~min}^{-1}$ compared to the slow reaction in the absence of a nanocatalyst. Such significant catalytic behavior of gold nanoparticles is due to the availability of a high surface area and a large number of active sites for the reactant molecules to interact by serving an electron relay effect [36].

Table 1. Synthesis of gold nanoparticles using different plant extracts and its degradation efficiency.

\begin{tabular}{|c|c|c|c|c|c|c|}
\hline Plant Materials & MNPs & Size and Shape & Organic Dyes & $\begin{array}{c}\text { Catalytic } \\
\text { Reagents/Sunlight }\end{array}$ & $\begin{array}{l}\text { Degradation (\%) or Rate } \\
\text { of Reaction (k) }\end{array}$ & Ref. \\
\hline $\begin{array}{l}\text { Persea americana } \\
\text { (Avocado) oil }\end{array}$ & AuNPs & $\begin{array}{l}48.8 \pm 24.8 \mathrm{~nm} \\
\text { spherical, decahedron } \\
\text { and triangular }\end{array}$ & MB & Sunlight & $\begin{array}{l}>84 \%, 10 \mathrm{mg} / \mathrm{L} \\
0.0057664 \mathrm{~min}^{-1}\end{array}$ & [25] \\
\hline $\begin{array}{l}\text { Capsicum baccatum } \\
\text { fruit }\end{array}$ & AuNPs & $\begin{array}{l}23.9 \pm 9.7 \mathrm{~nm} \\
\text { spherical }\end{array}$ & MB & Sunlight & $\begin{array}{c}>50 \%, \\
1.9585 \times 10^{-3} \mathrm{~min}^{-1}\end{array}$ & [29] \\
\hline Parkiarox burghii leaf & AuNPs & $\begin{array}{c}5-25 \mathrm{~nm}, \\
\text { quasi-spherical }\end{array}$ & $\begin{array}{c}\mathrm{MB} \text { and } \\
\text { Rhodamine B }\end{array}$ & Sunlight & 0.263 and $0.209 \mathrm{~min}^{-1}$ & {$[30]$} \\
\hline Alpinia nigra leaf & AuNPs & $21.52 \mathrm{~nm}$, spherical & $\begin{array}{c}\mathrm{MO} \text { and } \\
\text { Rhodamine } \mathrm{B}\end{array}$ & Sunlight & $83.25 \%$ and $87.64 \%$ & {$[31]$} \\
\hline $\begin{array}{l}\text { Garcinia indica Choissy } \\
\text { (Kokum) fruit }\end{array}$ & AuNPs & 20-30 nm, spherical & Methylene violet & $\begin{array}{l}\text { visible light, UV } \\
\text { light }\end{array}$ & $\begin{array}{l}89.17 \%, 0.014 \mathrm{~min}^{-1} \text { and } \\
86.02 \%, \mathrm{k}=0.0025 \mathrm{~min}^{-1}\end{array}$ & [32] \\
\hline Lantana camara flower & AuNPs & $\begin{array}{l}10.6 \pm 2.9 \mathrm{~nm} \\
\text { Spherical }\end{array}$ & MB & Sunlight & $>62 \%$ & [33] \\
\hline $\begin{array}{l}\text { Plukenetia volubilis } \\
\text { (Sacha inchi) oil }\end{array}$ & AuNPs & 5-15 nm, spherical & MB & Sunlight & $>75 \%, 3.263 \times 10^{-3} \mathrm{~min}^{-1}$ & {$[34]$} \\
\hline Mimosa pudica leaf & AuNPs & $16 \mathrm{~nm}$ & Rhodamine B & $\mathrm{NaBH}_{4}$ & $0.6319 \mathrm{~min}^{-1}$ & [36] \\
\hline Plumeria alba leaf & AuNPs & $28 \pm 5.6$, spherical & $\begin{array}{l}\text { MB, Eosin Y, MR, } \\
\text { CR, Ethidium } \\
\text { bromide }\end{array}$ & $\mathrm{NaBH}_{4}$ & $>80 \%$ & [37] \\
\hline Cassytha filiformis & AuNPs & $12 \mathrm{~nm}$, spherical & MB & Sunlight & $>87 \%$ & {$[38]$} \\
\hline $\begin{array}{c}\text { Cinnamomum tamala } \\
\text { leaf }\end{array}$ & $\mathrm{Au} / \mathrm{TiO}_{2}$ & 8-20 nm, spherical & MO & Sunlight & $0.346 \mathrm{~h}^{-1}$ & [39] \\
\hline
\end{tabular}


Table 1. Cont.

\begin{tabular}{|c|c|c|c|c|c|c|}
\hline Plant Materials & MNPs & Size and Shape & Organic Dyes & $\begin{array}{c}\text { Catalytic } \\
\text { Reagents/Sunlight }\end{array}$ & $\begin{array}{c}\text { Degradation (\%) or Rate } \\
\text { of Reaction (k) }\end{array}$ & Ref. \\
\hline $\begin{array}{c}\text { Dalbergia } \\
\text { coromandeliana root }\end{array}$ & AuNPs & $10.5 \mathrm{~nm}$, spherical & $\begin{array}{c}\text { Congo red and } \\
\text { MO }\end{array}$ & $\mathrm{NaBH}_{4}$ & $\begin{array}{c}4.5 \times 10^{-3} \mathrm{~s}^{-1} \text { and } \\
1.7 \times 10^{-3} \mathrm{~s}^{-1}\end{array}$ & [40] \\
\hline $\begin{array}{c}\text { Sterculia acuminate } \\
\text { fruit }\end{array}$ & AuNPs & $\begin{array}{l}9.37 \text { to } 38.12 \mathrm{~nm}, \\
\text { spherical }\end{array}$ & $\begin{array}{l}\mathrm{MB}, \mathrm{MO} \text { and } \\
\text { Direct blue }\end{array}$ & Sunlight & $\begin{array}{l}0.04314 \mathrm{~min}^{-1} \\
0.04502 \mathrm{~min}^{-1}, \\
0.00606 \mathrm{~min}^{-1}\end{array}$ & [41] \\
\hline $\begin{array}{c}\text { Pogestemon } \\
\text { benghalensis leaf }\end{array}$ & AuNPs & $\begin{array}{l}10-50 \mathrm{~nm} \text {, spherical } \\
\text { and triangular }\end{array}$ & MB & $\mathrm{NaBH}_{4}$ & $0.1758 \mathrm{~min}^{-1}$ & [42] \\
\hline $\begin{array}{c}\text { Mussaenda glabrata } \\
\text { leaf }\end{array}$ & AuNPs & $\begin{array}{l}10.59 \mathrm{~nm} \text {, spherical } \\
\text { and triangular }\end{array}$ & $\begin{array}{c}\text { Rhodamine B, } \\
\text { MO and } \\
\text { 4-Nitrophenol }\end{array}$ & $\mathrm{NaBH}_{4}$ & $\begin{array}{c}0.7250 \mathrm{~min}^{-1}, 3.8617 \\
\min ^{-1}, \text { and } 0.3426 \mathrm{~min}^{-1}\end{array}$ & [43] \\
\hline Glomus aureum fungus & AuNPs & $<250 \mathrm{~nm}$, irregular & MO & Sunlight & $45 \%$ & [44] \\
\hline $\begin{array}{c}\text { Sansevieria } \\
\text { roxburghiana leaf }\end{array}$ & AuNPs & $\begin{array}{l}\text { spherical, triangle, } \\
\text { hexagonal, rod and } \\
\text { decahedral }\end{array}$ & $\begin{array}{l}\text { Acridine orange, } \\
\text { Congo red, } \\
\text { Bromothymol } \\
\text { blue, } \\
\text { Phenol red, and } \\
\text { MB }\end{array}$ & $\mathrm{NaBH}_{4}$ & $\begin{array}{l}40.44 \%, 0.0673 \mathrm{~min}^{-1} \\
93.09 \%, 0.3320 \mathrm{~min}^{-1} \\
88.16 \%, 0.2092 \mathrm{~min}^{-1} \\
85.88 \%, 0.1202 \mathrm{~min}^{-1} \\
49.62 \%, 0.0118 \mathrm{~min}^{-1}\end{array}$ & [45] \\
\hline Spider cobweb & AuNPs & $40 \mathrm{~nm}$, spherical, & $\begin{array}{l}\text { Rhodamine B } \\
\text { andMB }\end{array}$ & Sunlight & $80.64 \%$ and $79.32 \%$ & [46] \\
\hline Angelica gigas stem & AuNPs & 20-80 nm, spherical & $\begin{array}{c}\text { Eosin } \mathrm{Y} \text { and } \\
\text { Malachite green }\end{array}$ & UV light & $83 \%$ and $65 \%$ & [47] \\
\hline
\end{tabular}

Mata et al. (2016) synthesized two different sizes of gold nanoparticles using 1\% and $5 \%$ concentrations of an aqueous extract of Plumeria alba flower. The formation of size-controlled gold nanoparticles showed SPR peaks at 552 and $536 \mathrm{~nm}$ corresponding to the spherical shape of nanoparticles of size $28 \pm 5.6$ and $15.6 \pm 3.4 \mathrm{~nm}$, respectively. Furthermore, the size-dependent catalytic activities of both gold nanoparticles were analyzed on six hazardous dyes, and the smaller-sized AuNPs exhibited higher catalytic activity than the larger nanoparticles. Not only catalytic activity but also the small-sized gold nanoparticles exhibited more pronounced antibacterial activity with an inhibition zone of $16 \mathrm{~mm}$ at a concentration of $400 \mu \mathrm{g} / \mathrm{mL}$ against Escherichia coli. The process of electron transfer between the $\mathrm{NaBH}_{4}$ donor and an acceptor dye in the presence of gold nanoparticles is the basic mechanism behind the catalysis [37]. Polyphenols-stabilized gold nanoparticles were synthesized using Cassytha filiformis plant extract. The average size of gold nanoparticles was found to be $12 \mathrm{~nm}$ and demonstrated photocatalytic degradation of cationic dye such as methylene blue by alkaline $\mathrm{pH}$ and sunlight. Green synthesized gold nanoparticles showed antimicrobial activity by confirming a significant inhibition of Mycobacterium smegmatis growth (zone of inhibition: $20 \mathrm{~mm}$ ). Additionally, the maximum dye loading capacity of gold nanoparticles were $595.23 \mathrm{mg} / \mathrm{g}$, and the dye degradation efficiency was found to be $87 \%$ after $20 \mathrm{~min}$ [38]. Naik et al. (2013) prepared $\mathrm{Au} / \mathrm{TiO}_{2}$ nanocomposites using the aqueous extract of Cinnamomum tamala leaves as the reductant via a green method [39]. Analytical characterization exhibited the formation of well-dispersed gold nanoparticles, which attached to the $\mathrm{TiO}_{2}$ surface. Furthermore, the nanogold/catalyst prepared by the green method was evaluated for the photocatalytic degradation of $\mathrm{MO}$ as a model reaction. It was found that the degradation rate of $\mathrm{MO}$ dyes using $\mathrm{Au} / \mathrm{TiO}_{2}$ nanocomposites was first-order kinetics with a rate constant of $0.346 \mathrm{~h}^{-1}$, and the nanocomposites modified with $2 \%$ by weight of gold nanoparticles exhibited 2.5 times higher degradation activity toward the $\mathrm{MO}$ dye compared to $\mathrm{TiO}_{2}$ under solar light irradiation. The effect of parameters such as $\mathrm{pH}$ and plant extract concentration has been evaluated on the morphology of AuNPs and photocatalytic degradation of $\mathrm{MO}$. The gold nanoparticles synthesized using a root extract containing 5, 7-dihydroxy-6-metoxy-3' 4' $^{\prime}$-methylenedioxyisoflavone (Dalspinin) of Dalbergia coromandeliana were first reported by Umamaheswari et al. (2018). The SPR observed at $532 \mathrm{~nm}$ and the TEM images confirmed that the synthesized gold nanoparti- 
cles were about $10.5 \mathrm{~nm}$ small, monodisperse, spherical form, and stable for more than 5 months without any aggregation. Whereas, the XRD-SAED pattern confirms the crystal nature of gold nanoparticles and showed good catalytic degradation of congo red and methyl orange, which followed the pseudo-first order kinetics, with a rate constant of $4.5 \times 10^{-3} \mathrm{~s}^{-1}\left(\mathrm{R}^{2}=0.9959\right)$ and $1.7 \times 10^{-3} \mathrm{~s}^{-1}\left(\mathrm{R}^{2}=0.9918\right)$, respectively [40].

In another investigation, Sterculia acuminate fruit extract was utilized for the biosynthesis of isotropic spherical gold nanoparticles as both reducing and capping agents. The size of the synthesized gold nanoparticles ranged from 9.37 to $38.12 \mathrm{~nm}$ and showed SPR at $539 \mathrm{~nm}$. It was also found that synthesized nanoparticles showed efficient catalytic reduction/degradation of different organic dyes including methylene blue $\left(\mathrm{k}=0.04314 \mathrm{~min}^{-1}\right)$, methyl orange $\left(\mathrm{k}=0.04502 \mathrm{~min}^{-1}\right)$, and direct blue $24\left(\mathrm{k}=0.00606 \mathrm{~min}^{-1}\right)$. The rate of degradation of methylene blue and methyl orange were found to be faster than other pollutants [41]. Paul et al. (2015) accomplished the biosynthesis of gold nanoparticles by reducing the $\mathrm{HAuCl}_{4}$ aqueous solution with Pogestemon benghalensis leaves. The UVvisible spectrum of the synthesized spherical and triangular gold nanoparticles with sizes $10-50 \mathrm{~nm}$ showed a surface plasmon resonance around $555 \mathrm{~nm}$ after $12 \mathrm{~h}$. The XRD pattern confirms the formation of a face-centered cubic structure of gold having an average crystallite size of $13.07 \mathrm{~nm}$. The catalytic degradation rate of $\mathrm{MB}$ dye using gold nanoparticles was found to be $0.1758 \mathrm{~min}^{-1}$ under visible light illumination [42]. Rapid microwave-assisted synthesis of gold and silver nanocatalysts using the aqueous leaf extract of Mussaenda glabrata was reported by Francis et al. (2017). Gold nanoparticles showed SPR peaks at $541 \mathrm{~nm}$, and the average size observed was $10.59 \mathrm{~nm}$ (spherical and triangular). The catalytic rate constant for gold nanoparticles using the reducing agent $\mathrm{NaBH}_{4}$ for rhodamine degradation was $\mathrm{k}=0.7250 \mathrm{~min}^{-1}$, whereas for methyl orange, it was $3.8617 \mathrm{~min}^{-1}$. It is suggested that anthropogenic pollutants were effectively remediated from aquatic environment and waste water sewages of dye industries using the prepared nanocatalyst [43] Ali et al. (2020) reported that the Glomus aureum fungus mediated extracellular biosynthesis of gold nanoparticles. The biosynthesized gold nanoparticles exhibited anti-bacterial potential and effective photocatalytic activity for the degradation of methyl orange dye (45\%) within $6 \mathrm{~h}$ under solar light illumination and also favors the ability of the nanocatalyst for the elimination of other toxic pollutants from water [44]. Kumar et al. (2019) synthesized multistructural gold nanoparticles using $2 \mathrm{mM}$ of chloroauric acid and an aqueous solution of Sansevieria roxburghiana leaf extract by $60 \mathrm{~min}$ at $40^{\circ} \mathrm{C}$. A mixture of spherical, trianglular, hexagonal, rod, and decahedral shaped gold nanoparticles was obtained [45]. It exhibited catalytic potential for the degradation of organic pollutants such as 4-nitrophenol $(87.98 \%$, $\left.\mathrm{k}=0.5098 \mathrm{~min}^{-1}\right)$, acridine orange $\left(40.44 \%\right.$ and $\left.\mathrm{k}=0.0673 \mathrm{~min}^{-1}\right)$, congo red $(93.09 \%$, $\left.\mathrm{k}=0.3320 \mathrm{~min}^{-1}\right)$, bromothymol blue $\left(88.16 \%, 0.2092 \mathrm{~min}^{-1}\right)$, phenol red $(85.88 \%$ and $\left.\mathrm{k}=0.1202 \mathrm{~min}^{-1}\right)$, and methylene blue $\left(49.62 \%\right.$ and $\left.0.0118 \mathrm{~min}^{-1}\right)$, respectively. In another study, gold nanoparticles fabricated from the novel biomaterial spider cobweb followed the hydrothermal path and also showed photocatalytic dye degradation. The synthesized gold nanoparticles showed a SPR at $540 \mathrm{~nm}$, spherical shape, well dispersed with an average size range of $40 \mathrm{~nm}$. Both dyes, rhodamine $\mathrm{B}(80.64 \%, 5 \mathrm{ppm}, 7 \mathrm{~h})$ and methylene blue $(79.32 \%$, $5 \mathrm{ppm}, 3 \mathrm{~h}$ ), were degraded with gold nanoparticles as a photocatalyst; this is due to more sensitivity to light and reduces the electron-hole recombination [46]. Chokkalingam et al. (2019) biofabricated gold nanoparticles by the method of green chemistry using an ecofriendly aqueous extract of Angelica gigasstem and had an important application of environmental remediation [47]. In this study, the synthesized gold nanoparticles exhibited photocatalytic degradation activity on eosin $Y(83 \%)$ and malachite green $(65 \%)$ dyes under UV irradiation.

\section{Silver Nanoparticles}

The fabrication of silver nanoparticles via a bottom-up approach with the desired quality is one of the most exciting aspects of modern nanoscience and nanotechnology. Metallic silver nanoparticles exhibit amazing photocatalytic activity during the irradiation 
of light under the UV-visible region due to its interb and transition of electrons. To date, numerous reports have shown that silver nanoparticles absorb electromagnetic radiation from 380 to $450 \mathrm{~nm}$, in the visible region by means of a phenomenon known as the excitation of LSPR [48]. Under the ultrasonic irradiation, the spherical shape of silver nanoparticles was synthesized by the $\mathrm{NaOH}$-starch reduction method and showed only one SPR band at $420 \mathrm{~nm}$ [49]. In addition, semicrystalline, silver nanoparticles with a spherical shape, a size around $15-80 \mathrm{~nm}$, and a wider band at $\lambda_{\max }=440 \mathrm{~nm}$ were observed when $\mathrm{AgNO}_{3}$ is treated with an aqueous extract of Andean cabbage as reducing and stabilizing agents (Figure 5a) [50] whereas, an average size of $20.5 \pm 1.5 \mathrm{~nm}$ obtained from Mortiño berry as the reductant is shown in Figure 5b. Their study confirmed that the nanoparticles organically coated with vitamins, polyphenolics, and anthocyanins of Mortiño berry were stable for one month with a slight change in UV-visible absorption at $\lambda_{\max } 405 \mathrm{~nm}$ [51]. All analytical characterization techniques reveal that the synthesized silver nanoparticles were highly dispersed, spherical with an average size of $20.5 \pm 1.5 \mathrm{~nm}$, stable, monodispersed, and face-centered cubic in nature. It showed a very high photocatalytic degradation activity against $\mathrm{MB}$ dye $\left(5 \mathrm{mg} / \mathrm{L}, \mathrm{k}=0.00707788 \mathrm{~min}^{-1}\right)$ under direct sunlight. Table 2 presents the synthesis of silver nanoparticles using different plant extracts and its degradation efficiency. The general reaction involving the synthesis of silver nanoparticles using plant extract:

$$
\mathrm{Ag}^{+}+-\mathrm{CHO} /-\mathrm{OH} \rightarrow \mathrm{Ag}^{0}+-\mathrm{COOH} / \mathrm{C}=\mathrm{O} .
$$

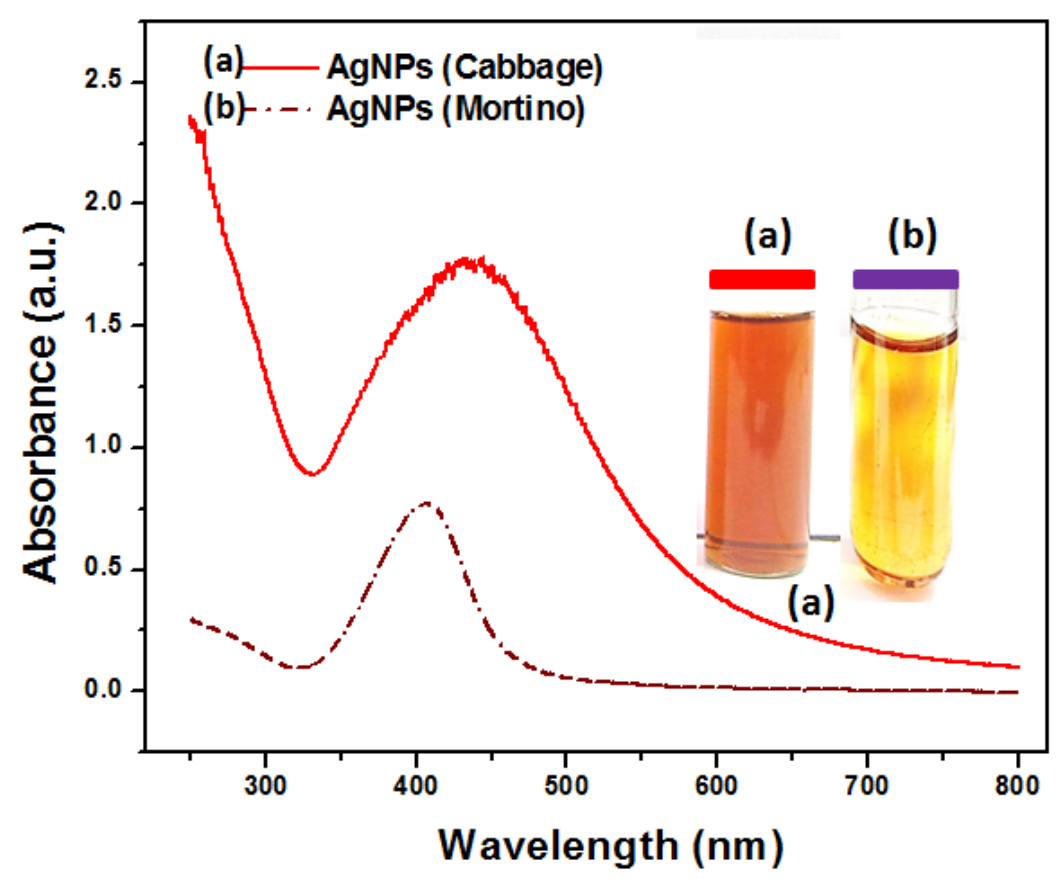

Figure 5. Visual and UV-Vis spectrum of silver nanoparticles synthesized using (a) Cabbage and (b) Mortino berry extract.

Alternatively, silver nanoparticles synthesized with gallic acid-chitosan using an ultrasound-assisted chemical reduction method were characterized by Guzmán et al. (2019). Their study demonstrated that the silver nanoparticles obtained were monodispersed, had a spherical shape with an average size of $26 \pm 10 \mathrm{~nm}$, showed a peak at $412 \mathrm{~nm}$, and were stable for four weeks without any noticeable change in size [52]. We have noticed that the size distributions of nanoparticles and their polydispersity are directly proportional to the width of the SPR, whereas the presence of two or more plasmonic resonances indicated silver nanoparticles of irregular shape, depending on the nanoparticles' symmetry. Kumar et al. (2014) synthesized silver nanoparticles in the presence of Sacha inchi oil and sunlight. The TEM characterization revealed that the nanostructure was highly dispersed, distorted cubic/square in shape, and $60 \mathrm{~nm}$ in size. Two absorption peaks around the 
wavelength of $380 \mathrm{~nm}$ and $480 \mathrm{~nm}$ confirm the presence of irregularly shaped silver nanoparticles in the solution and showed photocatalytic activity in the decomposition of the $\mathrm{MB}\left(10 \mathrm{mg} / \mathrm{L},>65 \%, \mathrm{k}=2.776 \times 10^{-3} \mathrm{~min}^{-1}\right)$ without using any reducing agent [53]. Sharma et al. (2018) reported green synthesized spherical silver nanoparticles using onion (Allium cepa) extract that vary in particle size from 50 to $100 \mathrm{~nm}$ with a zeta potential value of $-29 \mathrm{mV}$. Synthesized silver nanoparticles capped with the phenolic group have an excellent catalytic effect on the degradation of methylene blue, methyl red, eosin yellowish dye, safranin, direct, and reactive dye [54], respectively. Lantana camara L. is a notorious weed and popular ornamental garden plant with various flower colors, red, pink, white, yellow, and violet. Recently, Kumar et al. (2016) have synthesized silver nanoparticles using an ethanolic extract of L. camara flower as both the reducing and stabilizing agent. The synthesized silver nanoparticles are spherical with $33 \pm 5 \mathrm{~nm}$ average size and appeared at $470 \mathrm{~nm}$. It was found that the photocatalytic degradation rate constant $(\mathrm{k})$ for methylene blue was higher $\left(\mathrm{k}=3.40736 \times 10^{-3} \mathrm{~min}^{-1}\right)$ when $1 \mathrm{~mL}$ of silver nanoparticles were used and the percentage of optimized degradation was $70.20 \%$ at $10 \mathrm{mg} / \mathrm{L}$ of MB within $6 \mathrm{~h}$ [55]. Silver nanoparticles were synthesized using Angelica gigasstem stem, which explained their photocatalytic activity. The biosynthesized silver nanoparticles were spherical, showed a SPR at $414 \mathrm{~nm}$, and also exhibited photocatalytic degradation of eosin Y (67\%) and malachite green (64\%), respectively [47].

Vizuete et al. (2016) reported an environmentally friendly synthesis of spherical and 10-30 nm sized silver nanoparticles at $\lambda_{\max }=423 \mathrm{~nm}$ by reducing silver ions using fruit extracts of Shora (Capparis petiolaris) and sunlight. It has shown that the sunlight irradiation step is more useful compared to other parameters such as $\mathrm{pH}$, concentration, or temperature for the synthesis of silver nanoparticles. Furthermore, the synthesized nanoparticles showed photocatalytic activity and are well fitted by a first-order rate law for the degradation of MB $\left(>58 \%, k=0.0025293163 \mathrm{~min}^{-1}\right)$ [56]. Arunachalam et al. (2012) presented a Coccinagrandis leaf extract-mediated bioreductive synthesis of 20-30 nm-sized Ag particles and demonstrated the use of an ecofriendly and low-cost biological reducing agent to generate metallic nanoparticles. Synthesized nanoparticles were crystallized in a facecentered cubic symmetry, exhibited photocatalytic activity by degradation of Coomassie Brilliant Blue G-250 under UV light, and may be used for water purification systems in the future [57]. The rapid microwave-assisted biofabrication of silver nanoparticles using leaf extract (aq) of Mussaenda glabrata was studied by Francis et al. (2017). They concluded that the SPR peak at $415 \mathrm{~nm}$ corresponds to the spherical shape of silver nanoparticles of average size $51.32 \mathrm{~nm}$ and showed lower degradation of rhodamine $\left(\mathrm{k}=0.4464 \mathrm{~min}^{-1}\right)$ and methyl orange $\left(\mathrm{k}=0.7910 \mathrm{~m}^{-1}\right)$ with respect to the synthesized gold nanoparticles [43]. Kou and Varma (2014) explored a microwave-irradiated, fast (within $5 \mathrm{~min}$ ), and green synthesis of hybrid $\mathrm{AgCl} / \mathrm{Ag}$ plasmon nanoparticles using beet root juice. Interestingly, beet juice containing a sugar-rich agricultural product served as a reducing reagent, and the obtained size of $\mathrm{AgCl} / \mathrm{Ag}$ nanocomposites was smaller than the $\mathrm{AgCl}$ reaction precursor. This bottom-up hydrothermal synthesis of the prepared nanomaterial displayed good photocatalytic activity for the degradation of the MO dye [58]. In another study, cheaply available Sacha inchi shell biomass (SISB) was reported for the biosynthesis of monodispersed silver nanoparticles and showed photocatalytic activity for the remediation of methyl orange dye. Optical and microscopic techniques have indicated that the SPR at $420 \mathrm{~nm}$ corresponds to the spherical shape with $7.2 \mathrm{~nm}$ sized silver nanoparticles. In addition, the experimental evidence showed that the maximum photocatalytic effect for the removal of $\mathrm{MO}$ was observed at $\mathrm{pH} 2(\approx 60 \%, 5 \mathrm{~h}, 64 \mathrm{mg} / \mathrm{L})$ in the presence of silver nanoparticles and sunlight with a rate constant $\mathrm{k}=0.0008898 \mathrm{~min}^{-1}$ [59]. The results of the FTIR revealed that an organic layer formed around the silver nanoparticles and the reduction of $\mathrm{Ag}^{+}$to $\mathrm{Ag}^{0}$ had mostly been carried out by polysaccharides present in SISB Figure 6a shows that the FTIR absorption spectrum of SISB-coated silver nanoparticles at $3286 \mathrm{~cm}^{-1}$ corresponds to $-\mathrm{NH}_{2}$ and $-\mathrm{OH}$ groups due to the presence of a macromolecular association in cellulose, pectin, etc. The bands at $1597 \mathrm{~cm}^{-1}, 1242 \mathrm{~cm}^{-1}$, and $1030 \mathrm{~cm}^{-1}$ 
are observed as $\mathrm{CO}-\mathrm{NH}-,-\mathrm{SO}_{3}$, and $\mathrm{C}-\mathrm{O}-\mathrm{C}$ stretching vibrations in the amide linkages, sulfate, and glycoside in the SISB, correspondingly [59]. In contrast, Figure $6 \mathrm{~b}$ shows FTIR spectrum of silver nanoparticles synthesized by Taxo (Passiflora tripartita) fruit extract. The peak around $3339 \mathrm{~cm}^{-1}$ was attributed to the $\mathrm{O}-\mathrm{H}$, either alcoholic or polyphenolic stretching, and those at $2946-2834 \mathrm{~cm}^{-1}$ indicated $\mathrm{C}-\mathrm{H}$ (aliphatic) stretching. The peak located at $1654 \mathrm{~cm}^{-1}$ represented the $\mathrm{C}=\mathrm{O}$ stretching in the carboxyl or $\mathrm{C}=\mathrm{C}-\mathrm{C}=\mathrm{O}$ stretching in the conjugated carboxyl. The vibrational peak observed at $1019 \mathrm{~cm}^{-1}$ corresponds to secondary $-\mathrm{OH}$ stretching, indicating that the secondary $-\mathrm{OH}$ also participates in nanoparticles synthesis. P. tripartita pigments are mainly composed of glucose, C-glycosides, and O-glycoside derivatives as functional groups [27], which may be participated in reducing the $\mathrm{Ag}^{+}$to $\mathrm{Ag}^{0}[60]$.

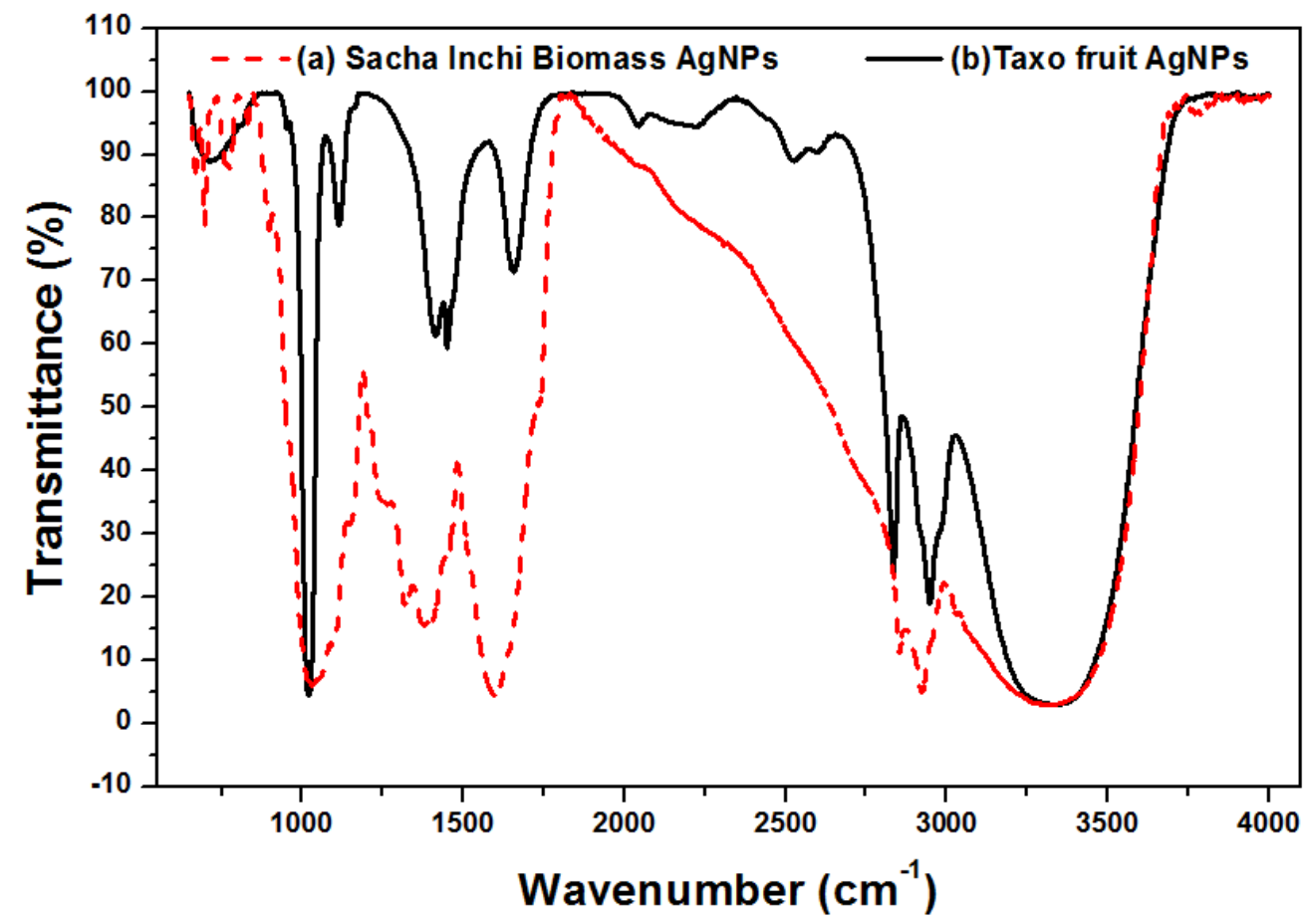

Figure 6. FTIR spectrum of silver nanoparticles synthesized using Taxo fruit and Sacha inchi shell biomass extract.

Vanaja et al. (2014) prepared silver nanoparticles using Morinda tinctoria leaf extract under different $\mathrm{pH}$ conditions, and the synthesized nanoparticles were further characterized by different optical, microscopic, and spectroscopic techniques. They concluded that the size as well as the quantity of silver nanoparticles formed are strongly dependent on the $\mathrm{pH}$, and basic $\mathrm{pH}$ supports the biosynthesis of silver nanoparticles, whereas no silver nanoparticles were detected in the acid medium. Spherical-shaped silver nanoparticles were prepared with size ranging from 79 to $96 \mathrm{~nm}$ and showed photocatalytic activity by degrading the MB dye (95\%), efficiently [61]. Varadavenkatesan et al. (2016) reported a simple, rapid, and non-hazardous method for synthesizing silver nanocatalyst using Mussaenda erythrophylla leaf extract. It displayed a distinct SPR peak at $414 \mathrm{~nm}$ corresponding to the UV-visible spectrum of silver nanoparticle. SEM and EDAX analysis confirmed the formation of sub-100 nm sized particles and the existence of elemental silver in the sample. In contrast, the zeta potential value of $-47.7 \mathrm{mV}$ and XRD analysis define the good stability and the face-centered cubic crystalline nature of the silver nanoparticles. The synthesized silver nanocatalysts were exploited to degrade the $\mathrm{MO}$ using $\mathrm{NaBH}_{4}$ as a reductant [62]. Not only silver nanoparticles, Kumar et al. also synthesized silver-doped titanium dioxide nanoparticles $\left(\mathrm{Ag} / \mathrm{TiO}_{2} \mathrm{NPs}\right)$ using Nephelium lappaceum $\mathrm{L}$. peel extracts in an ecologically and economically favorable way. A wide range of spectroscopy and 
microscopy techniques were performed to ascertain the synthesis of $\mathrm{Ag} / \mathrm{TiO}_{2} \mathrm{NPs}$ and the study of its photocatalytic activity on the MB dye. The synthesized $\mathrm{Ag} / \mathrm{TiO}_{2} \mathrm{NPs}$ enhanced the photocatalytic degradation activity of $\mathrm{MB}\left(81.6 \%, \mathrm{k}=0.002495 \mathrm{~min}^{-1}\right)$ under direct solar light irradiation and highlighted the use of discarded agricultural waste in wastewater remediation [63]. In 2017, Bordbar reported on the successful design and preparation of silver nanoparticles immobilized on the waste almond shell surface (AgNPs/almond shell) using phenolic acid or flavonoids of Ruta graveolens leaf extract and investigated its catalytic performance in the reducing $\mathrm{MB}$, rhodamine $\mathrm{B}$, and 4-NP at room temperature. The 5-15 nm sized heterogeneous AgNPs/almond shell nanocatalyst is easily prepared and can be recycled and reused seven times without significant loss of activity [64]. Punica granatum or pomegranate fruits were characterized by their high polyphenol content and antioxidant properties. Meena Kumari and Philip (2015) first reported the P. granatum fruit juice-mediated biogenic reduction and stabilization of gold and silver ions at room temperature. The formation, morphology, and crystalline structure of the synthesized silver and gold nanoparticles were determined using different analytical techniques, whereas FTIR confirmed the partial role of phenolic hydroxyls in the reduction of $\mathrm{Au}^{3+}$ and $\mathrm{Ag}^{+}$ to $\mathrm{Au}^{0}$ and $\mathrm{Ag}^{0}$. The synthesized silver and gold nanocatalyst showed dye degradation, and the rate constants were well fitted with pseudo first-order kinetic data. Kinetic data plots suggest the fast removal of $\mathrm{MB}$ in the presence of gold nanocatalyst and $\mathrm{MO}$ in the presence of silver nanocatalyst. It can be concluded that the catalytic activity of gold nanoparticles is in the order of $\mathrm{MB}>\mathrm{MO}>\mathrm{EY}$, while that of silver nanoparticles is in the order of MO $>$ EY > MB [65]. Edison et al. (2016) showed the efficacy of Terminalia cuneata bark extract synthesized silver nanoparticles to catalyze the reduction of direct yellow-12. The major phytoconstituents present in the extracts of T. cuneata were mostly tannins and polyphenols, which act as reducers as well as capping agents and provide stability to silver nanoparticles, as evident in the FTIR study. The phytosynthesized silver nanoparticles were crystalline, face-centered cubic geometry oriented in the (111) plane and had a distorted spherical shape with the size ranging approximately from 25 to $50 \mathrm{~nm}$. A complete decolorization of direct yellow-12 was observed within $40 \mathrm{~min}$ in the presence of silver nanoparticles and $\mathrm{NaBH}_{4}$ [66].

Kaviya and Prasad (2015) developed a green methodology for the synthesis of the $\mathrm{ZnO}-\mathrm{Ag}$ nanocomposite using pomegranate peel extract as a reductive and stabilizing agent [67]. Based on the SEM, TEM, and HRTEM images, the prepared ZnO-Ag nanocomposite was well dispersed, had a custard-apple shape, and had a size around $\approx 100 \mathrm{~nm}$. The good dispersion of silver nanoparticles on $\mathrm{ZnO}$ and the uniform shape lead to excellent charge separation, cause better photocatalytic action in MB degradation, and means they can be reused for five cycles without losing catalytic action. Gupta et al. (2011) evaluated the nature of nanoparticles for the catalytic decomposition of $\mathrm{MO}$ in the presence of sodium borohydride. They synthesized spherical and $10 \mathrm{~nm}$ size of gold, silver, and platinum nanoparticles by reducing the corresponding salt using tannic acid. The silver nanoparticles have an enhanced catalytic effect compared to gold and platinum $\left(\mathrm{k}_{\mathrm{AgNPs}}>>\mathrm{k}_{\text {AuNPs }}>\mathrm{k}_{\mathrm{Pt}} \mathrm{NPs}>\mathrm{k}_{\text {uncatalyzed }}\right)$ on MO degradation due to the low value of silver work function compared to gold and platinum. Since sodium borohydride is such a strong reducing agent, it is not able to reduce methyl orange in the absence of a catalyst, indicating the catalytic efficacy of metal nanoparticles [68]. In 2018, Veisi et al. prepared spherical silver nanoparticles using Thymbra spicata leaf extract via $\mathrm{Ag}^{+}$ion reduction using polyphenolic compounds and flavonoids present in the extract. The green synthesized silver nanoparticles displayed high catalytic activity in the reduction of 4-nitrophenol, rhodamine $\mathrm{B}$, and methylene blue by sodium borohydride in $\mathrm{H}_{2} \mathrm{O}$ under mild conditions, and this heterogeneous catalyst could be used in eight cycles without significant loss of activity [69]. In 2017, a green and mild method was suggested by Khodadadi for the preparation of Ag/Hazelnut shell nanocomposites using Origanum vulgare leaf extract in the absence of any surfactant. The nanocomposite was prepared by reducing the $\mathrm{Ag}^{+}$ions into silver nanoparticles and their immobilization on the hazelnut shell surface using the 
hydroxyl groups of the phenolic present in the extract. Furthermore, it exhibited high catalytic activity and can be reused for five cycles in the reduction of methyl orange and Congo red using $\mathrm{NaBH}_{4}$ as a reducing agent [70]. In another study, Wang et al., 2018 developed an ecofriendly procedure for the biosynthesis of silver nanoparticles with the reduction of $\mathrm{Ag}^{+}$to $\mathrm{Ag}^{0}$ by flavonoid fractions of the leaves of Psidium guajava. The results showed that stable spherical silver nanoparticles were prepared within $10 \mathrm{~min}$ and showed an SPR peak at $420 \mathrm{~nm}$ with a particle size of $15-20 \mathrm{~nm}$. As-prepared silver nanoparticles exhibited good catalytic degradation potency for methyl orange and Coomassie brilliant blue G-250, under solar or UV irradiation [71]. In 2016, a group of researchers used a paper wasp (Polistes sp.) nest extract for the synthesis of silver nanoparticles. The prepared nanoparticles were crystalline, polydispersed, and anisotropic in shape, including spherical, triangular, hexagonal, rod, and rhombus with size ranges from 12.5 to $95.55 \mathrm{~nm}$. The synthesized nanoparticles showed (a) 93.1\% degradation of malachite green dye, (b) excellent antimicrobial activity against multi-drug-resistant bacteria and fungi, (c) blood anticoagulation, and thrombolytic activities [72].

In 2017, Qing et al. succeeded in synthesizing silver nanoparticles using waste tea extract as a reducing and capping agent. The green synthesized silver nanoparticles were characterized by different analytical techniques and exhibited a catalytic degradation activity against cationic dyes of more than $65 \%$, but there was no catalytic degradation of anionic dyes at room temperature, and it follows a pseudo-second-order model for dye degradation [73]. In another study, Raj et al. (2020) biosynthesized highly stable silver nanoparticles by a cheap and eco-friendly method using leaf extract of Terminalia arjuna and employing it as a catalyst for removing hazardous dyes such as methyl orange, methylene blue, congo red, and 4-nitrophenol. The organically coated and reddish-brown color silver nanoparticles showed a single SPR peak at $418 \mathrm{~nm}$ and a spherical shape of particles of size ranged between 10 and $50 \mathrm{~nm}$ confirmed by microscopic studies. The XRD analysis proved the face-centered cubic crystalline nature, whereas the negative value of the zeta potential (-21.7) indicated the stability of the silver nanoparticles. The synthesized nanoparticles exhibited strong dye degradation and followed the pseudo-firstorder reaction kinetics as $\mathrm{MO}\left(86.68 \%, \mathrm{k}=0.166 \mathrm{~min}^{-1}\right), \mathrm{MB}\left(93.60 \%, \mathrm{k}=0.138 \mathrm{~min}^{-1}\right)$, CR $\left(92.20 \%, \mathrm{k}=0.182 \mathrm{~min}^{-1}\right)$, and $4 \mathrm{NP}\left(88.80 \%, \mathrm{k}=0.142 \mathrm{~min}^{-1}\right)$, respectively [74]. In 2016, Vanaamudan et al. reported the preparation of silver nanoparticles using palm shell extract [70]. It is suggested that the presence of hydroxyl, carbonyl, and carboxyl groups in the extract could be responsible for the process of reduction and complexation during nanoparticle synthesis. Silver nanoparticles showed potential catalytic performance in the degradation of copper phthalocyanine-based dye-Reactive blue-21, azo dyereactive Red-141, and a xanthene dye-rhodamine 6G (Rh-6G) dye as well as their binary combinations using $\mathrm{H}_{2} \mathrm{O}_{2}$. In this study, the radicals formed during the oxidation of silver nanoparticles by $\mathrm{H}_{2} \mathrm{O}_{2}$ could be utilized for dye degradation [75]. David and Moldovan also reported a green method of synthesizing silver nanoparticles using the fruit extract of Viburnum opulus L. as a source of bioactive compounds, which can act as reducing agents of the silver ions and also as stabilizing agents of the obtained nanoparticles. Biosynthesized silver nanoparticles were confirmed by various spectroscopic and microscopic analyses. It showed the characteristic absorption peak at $415 \mathrm{~nm}$ corresponding to the surface plasmon vibration of colloidal silver, and the nanoparticles obtained were spherical in shape, with an average diameter of $16 \mathrm{~nm}$, monodispersed, and face-centered cubic crystal form. The catalytic ability of silver nanoparticles in the degradation of tartrazine, carmoisine, and brilliant blue FCF dyes was studied by $\mathrm{NaBH}_{4}$, in which the results for the degradation of brilliant blue FCF were outstanding [76]. In 2016, Patil et al. suggested a green and facile hydrothermal route for the preparation of $10-50 \mathrm{~nm}$ sized silver-zinc oxide nanostructures using Azadirachta indica leaf extract. According to the results obtained, the prepared nanostructures showed face-centered cubic and wurtzite structure for silver and $\mathrm{ZnO}$. It exhibited effective and faster photodegradation of $\mathrm{MB}$ in an aqueous medium under natural sunlight compared to the untreated $\mathrm{ZnO}$ nanostructure [77]. 
Table 2. Synthesis of silver nanoparticles using different plant extracts and their degradation efficiency.

\begin{tabular}{|c|c|c|c|c|c|c|}
\hline Plant Materials & MNPs & Size and Shape & Organic Dyes & $\begin{array}{c}\text { Catalytic } \\
\text { Reagents/Sunlight }\end{array}$ & $\begin{array}{l}\text { Degradation (\%) or } \\
\text { Rate of Reaction (k) }\end{array}$ & Ref. \\
\hline $\begin{array}{l}\text { Andean Mortino } \\
\text { berry }\end{array}$ & AgNPs & $\begin{array}{l}20.5 \pm 1.5 \\
\text { spherical }\end{array}$ & MB & Sunlight & $0.00707788 \mathrm{~min}^{-1}$ & [51] \\
\hline $\begin{array}{l}\text { Plukenetia volubilis } \\
\text { (Sacha inchi) oil }\end{array}$ & AgNPs & $\begin{array}{c}60 \mathrm{~nm}, \\
\text { cubic/square }\end{array}$ & MB & Sunlight & $\begin{array}{c}>65 \% \\
2.776 \times 10^{-3} \mathrm{~min}^{-1}\end{array}$ & [53] \\
\hline Allium сера (onion) & AgNPs & $\begin{array}{l}50 \text { to } 100 \mathrm{~nm}, \\
\text { spherical }\end{array}$ & $\begin{array}{c}\text { MB, MR, Eosin } \\
\text { yellowish, Safranin, } \\
\text { direct and reactive } \\
\text { dye }\end{array}$ & $37^{\circ} \mathrm{C}$, visible light & $>80 \%$ & [54] \\
\hline Lantana camara flower & AgNPs & $\begin{array}{l}33 \pm 5 \mathrm{~nm} \\
\text { spherical }\end{array}$ & MB & Sunlight & $\begin{array}{c}70.20 \% \\
3.407 \times 10^{-3} \min ^{-1}\end{array}$ & [55] \\
\hline Angelica gigas stem & AgNPs & spherical & $\begin{array}{c}\text { Eosin } \mathrm{Y} \text { and } \\
\text { Malachite green }\end{array}$ & UV light & $67 \%$ and $64 \%$ & [47] \\
\hline Capparis petiolaris fruit & AgNPs & $\begin{array}{l}10-30 \mathrm{~nm}, \\
\text { spherical }\end{array}$ & MB & Sunlight & $\begin{array}{c}>58 \% \\
2.53 \times 10^{-3} \min ^{-1}\end{array}$ & [56] \\
\hline Coccinia grandis leaf & AgNPs & $\begin{array}{l}\text { 20-30 nm, } \\
\text { spherical }\end{array}$ & $\begin{array}{l}\text { Coomassie Brilliant } \\
\text { Blue G-250 }\end{array}$ & Fluorescent UV light & $>30 \%, 90 \mathrm{~min}$ & [57] \\
\hline $\begin{array}{c}\text { Mussaenda glabrata } \\
\text { leaf }\end{array}$ & AgNPs & $\begin{array}{l}51.32 \mathrm{~nm}, \\
\text { spherical }\end{array}$ & $\begin{array}{l}\text { Rhodamine } \mathrm{B}, \mathrm{MO} \\
\text { and 4-Nitrophenol }\end{array}$ & $\mathrm{NaBH}_{4}$ & $\begin{array}{c}0.4464 \mathrm{~min}^{-1}, \\
0.7910 \mathrm{~min}^{-1} \text {, and } \\
0.0943 \mathrm{~min}^{-1}\end{array}$ & [43] \\
\hline Beet root & $\begin{array}{c}\mathrm{AgCl} / \mathrm{Ag} \\
\mathrm{NPs}\end{array}$ & $100 \mathrm{~nm}$, spherical & $\mathrm{MO}$ & Xe arc lamp & $>98 \%, 60 \mathrm{~min}$ & [58] \\
\hline $\begin{array}{l}\text { Sacha inchi Shell } \\
\text { biomass (SISB) }\end{array}$ & AgNPs & $7.2 \mathrm{~nm}$, spherical & MO & Sunlight & $60 \%, 0.0008898 \mathrm{~min}^{-1}$ & [59] \\
\hline Morinda tinctoria leaf & AgNPs & $\begin{array}{l}\text { 79-96 nm, } \\
\text { spherical }\end{array}$ & MB & Sunlight & $95.3 \%$ at $72 \mathrm{~h}$ & [61] \\
\hline $\begin{array}{c}\text { Mussaenda } \\
\text { erythrophylla leaf }\end{array}$ & AgNPs & $\begin{array}{l}82-88 \mathrm{~nm}, \\
\text { spherical }\end{array}$ & MO & $\mathrm{NaBH}_{4}$ & $>50 \%, 45 \mathrm{~min}$ & [62] \\
\hline Rambutan Peel & $\mathrm{Ag} @ \mathrm{TiO}_{2}$ & Spherical & MB & Sunlight & $\begin{array}{c}81.6 \% \\
0.002495 \mathrm{~min}^{-1}\end{array}$ & [63] \\
\hline Punica granatum fruit & AgNPs, & $36 \mathrm{~nm}$, spherical & $\mathrm{MB}, \mathrm{MO}, \mathrm{Eosin} \mathrm{Y}$ & $\mathrm{NaBH}_{4}$ & $83 \%, 99 \%, 96 \%$ & [65] \\
\hline Terminalia cuneate bark & AgNPs & $25-50 \mathrm{~nm}$ & Direct yellow-12 & $\mathrm{NaBH}_{4}$ & $>95 \%, 40 \mathrm{~min}$ & [66] \\
\hline Thymbra spicata leaf & AgNPs & $7 \mathrm{~nm}$, spherical & $\begin{array}{l}\text { 4-Nitrophenol, } \\
\text { Rhodamin B, MB }\end{array}$ & $\mathrm{NaBH}_{4}$ & $\begin{array}{c}6.45 \times 10^{-2} \mathrm{~s}^{-1} \\
5.74 \times 10^{-2} \mathrm{~s}^{-1} \text { and } \\
8.64 \times 10^{-2} \mathrm{~s}^{-1}\end{array}$ & [69] \\
\hline Psidium guajava leaf & AgNPs & $\begin{array}{l}\text { 15-20 nm, } \\
\text { spherical }\end{array}$ & $\begin{array}{l}\mathrm{MO} \text { and Coomassie } \\
\text { brilliant blue G-250 }\end{array}$ & Sunlight/UV light & $>60 \%$ & [71] \\
\hline Terminalia arjuna leaf & AgNPs & $\begin{array}{l}10-50 \mathrm{~nm}, \\
\text { spherical }\end{array}$ & $\begin{array}{l}\text { MO, MB, Congo red, } \\
\text { and 4- Nitrophenol }\end{array}$ & $\mathrm{NaBH}_{4}$ & $\begin{array}{l}86.68 \%, 0.166 \mathrm{~min}^{-1} ; \\
93.60 \%, 0.138 \mathrm{~min}^{-1} ; \\
92.20 \%, 0.182 \mathrm{~min}^{-1} ; \\
88.80 \%, 0.142 \mathrm{~min}^{-1}\end{array}$ & [74] \\
\hline Viburnum opulus fruit & AgNPs & $16 \mathrm{~nm}$, spherical & $\begin{array}{c}\text { Tartrazine, } \\
\text { Carmoisine and } \\
\text { Brilliant blue FCF }\end{array}$ & $\mathrm{NaBH}_{4}$ & $28 \%, 45 \%, 38 \%$ & [76] \\
\hline
\end{tabular}

\section{Iron and Iron Oxide Nanoparticles}

In recent years, the preparation and application of nano-scale zero valent iron $\left(\mathrm{nZVI} / \mathrm{Fe}^{0}\right)$ and iron oxide nanoparticles (FeONPs) with novel properties and functions have been widely studied, due to their nano-range size, high surface area to volume ratios, superparamagnetism, and unique physicochemical properties, especially in environmental remediation practices. As the particle size decreases, the proportion of surface and near surface atoms increases. Surface atoms tend to have more unsatisfied or dangling bonds with concomitantly higher surface energy. Thus, the surface atoms have a stronger tendency to interact, adsorb, and react with other atoms or molecules in order to achieve surface stabilization. Among all iron nanoparticles, nZVI has excellent electron-donating 
properties and it is fairly reactive in water under ambient conditions, making it a versatile remediation material [78].

Iron oxide nanoparticles with different polymorph structures have been extensively studied for environmental remediation due to their extensive applications throughout contemporary science and technological innovation. The most popular iron oxide nanoparticles are the magnetite $\left(\mathrm{Fe}_{3} \mathrm{O}_{4}\right.$, ferrimagnetic, superparamagnetic when the size is less than $15 \mathrm{~nm})$, maghemite $\left(\gamma-\mathrm{Fe}_{2} \mathrm{O}_{3}\right.$, ferrimagnetic), hematite $\left(\alpha-\mathrm{Fe}_{2} \mathrm{O}_{3}\right.$, weakly ferromagnetic or antiferromagnetic), and $\mathrm{FeO}$ (wustite, antiferromagnetic), among which magnetite and maghemite are very promising and popular candidates, since its biocompatibility has already been proven [79]. The $\alpha-\mathrm{Fe}_{2} \mathrm{O}_{3}$ is a nontoxic, inexpensive, stable, and abundant material possessing a suitable bandgap of $2.2 \mathrm{eV}$. It has provided purposes through catalysts, high density permanent magnetic storage media, solar energy conversion, water splitting, pigments, water purification, gas sensors, and anti-corrosive agents. It can be activated by visible light radiation and is an extremely active catalyst for the photodegradation of organic pollutants [80]. The $\mathrm{Fe}_{3} \mathrm{O}_{4}$ and $\gamma-\mathrm{Fe}_{2} \mathrm{O}_{3}$ nanoparticles are widely used in permanent magnetic resonance image resolution (MRI) as contrast agents, for hyperthermia cell labeling, as ferrofluids, for anticancer therapies, for targeting drug delivery, and for separation due to their nontoxicity and biocompatibility. $\mathrm{Fe}_{3} \mathrm{O}_{4}$, which is a black ferromagnetic iron oxide of both $\mathrm{Fe}(\mathrm{II})$ and $\mathrm{Fe}(\mathrm{III})$, has been the most extensively studied because of the presence of the $\mathrm{Fe}^{2+}$ state with the potential to act as an electron donor [81].

In 2009, Hoag et al. synthesized nZVI at room temperature with tea (Camellia sinensis) polyphenols and their formation indicated by color changes in the reaction mixture from pale yellow to dark greenish/black within a few minutes. The results revealed that as the concentration of nZVI increases, the surface area to volume ratio of nano iron increases, the catalytic rate of $\mathrm{H}_{2} \mathrm{O}_{2}$ also increases, and the highest rate of degradation of bromothymol blue occurs $\left(\mathrm{k}=0.1447 \mathrm{~min}^{-1}\right)$ [82]. Kumar et al. (2016) efficiently developed the synthesis of spherical magnetite nanoparticles $\left(\mathrm{Fe}_{3} \mathrm{O}_{4} \mathrm{NPs}\right)$ mediated by Andean blackberry (Rubus glaucus Benth) leaf. The suggested method is simple, low cost, and ecofriendly, and blackberry leaf containing flavonoids, ellagic acid, tannins, etc. can replace the use of toxic chemicals for the biosynthesis of magnetite nanoparticles. It has been reported that synthesized $\mathrm{Fe}_{3} \mathrm{O}_{4} \mathrm{NPs}$ with an average size of $54.5 \pm 24.6 \mathrm{~nm}$ exhibited photocatalytic degradation activity of organic dyes such as $\mathrm{MB}\left(\mathrm{k}=0.0105475 \mathrm{~min}^{-1}\right), \mathrm{CR}$ $\left(\mathrm{k}=0.0043240 \mathrm{~min}^{-1}\right)$, and $\mathrm{MO}\left(\mathrm{k}=0.0028930 \mathrm{~min}^{-1}\right)$, efficiently [83]. The control of the size and morphology is not straightforward, because plant extracts are composed of a number of components. Huang et al. (2014) synthesized iron nanoparticles (FeNPs) using green, Oolong, and black tea extracts (caffeine/polyphenols) as reducing and capping agents, instead of using environmentally toxic sodium borohydride. They concluded that the best method of degrading malachite green dye was FeNPs synthesized with green tea extracts. Furthermore, the kinetics for the degradation of malachite green using FeNPs, which are well fitted to a pseudo-first-order reaction kinetics model with an activation energy of more than $20 \mathrm{~kJ} / \mathrm{mol}$, suggest a chemically diffusion-controlled reaction. The degradation of malachite green dye with FeNPs was due to the adsorption of dye to FeNPs, oxidation of iron, and cleaving of the $\mathrm{C}=\mathrm{C}-$ and $=\mathrm{C}=\mathrm{N}-$ bond, which was connected with the benzene ring [84]. Table 3 presents the synthesis of iron/iron oxide nanoparticles using different plant extracts and its degradation efficiency.

$$
\begin{gathered}
\mathrm{Fe}^{3+}+3 \mathrm{H}_{2} \mathrm{O} \rightarrow \mathrm{Fe}(\mathrm{OH})_{3} \downarrow+3 \mathrm{H}^{+}(\mathrm{pH}>9 \sim 10) \\
\mathrm{Fe}(\mathrm{OH})_{3} \downarrow+-\mathrm{CHO} /-\mathrm{OH} \rightarrow \text { Complexation } \rightarrow \mathrm{Fe}^{0} \downarrow / \mathrm{FeO} \downarrow / \alpha-\mathrm{Fe}_{2} \mathrm{O}_{3} \mathrm{NPs} \downarrow / \gamma-\mathrm{Fe}_{2} \mathrm{O}_{3} \mathrm{NPs} \downarrow \\
\mathrm{FeO}+\alpha-\mathrm{Fe}_{2} \mathrm{O}_{3}+(-\mathrm{CHO} /-\mathrm{OH})+\text { Heat }\left(78-80^{\circ} \mathrm{C}\right) \rightarrow \mathrm{Fe}_{3} \mathrm{O}_{4} \mathrm{NPs} \downarrow+\text { Carbonic acid (R-COOH) }
\end{gathered}
$$

Recently, $\mathrm{Fe}_{3} \mathrm{O}_{4}$ nanoparticles were synthesized by Cynara cardunculus leaf extract, and Ruíz-Baltazar et al. (2019) presented a novel, green, and eco-friendly synthetic route for producing iron oxides nanoparticles. The structural characterization of the $\mathrm{Fe}_{3} \mathrm{O}_{4}$ nanoparticles was carried out by different characterization techniques, including Raman 
spectroscopy. The synthesized $\mathrm{Fe}_{3} \mathrm{O}_{4} \mathrm{NPs}$ showed a catalytic degradation activity against methylene blue dye, and their degradation rate/kinetic adsorption behavior is governed by the pseudo-second-order model (type 2). This may be due to the ionic exchange and chemisorption process between the positive partial charges of the $\mathrm{Fe}_{3} \mathrm{O}_{4}$ nanoparticles and the molecule of the MB [85]. Luo et al. (2015) proposed a single-step synthesis of $\mathrm{nZVI} / \mathrm{Fe}^{0} \mathrm{NPs}$ using grape leaf extract, and a cost-effective method for the in situ rapid remediation of effluent containing Orange II is suggested. Kinetic studies confirm that $>92 \%$ of Orange II has been removed by FeNPs at high temperature, which were based on adsorption and reduction processes. Different spectroscopic and microscopic analyses showed that the FeNPs were composed of phytochemicals, hydrous iron oxides, and $\mathrm{Fe}^{0}$, thus providing evidence of the adsorption of Orange II onto hydrous iron oxides and its reduction by $\mathrm{Fe}^{0}$. The LC-MS analysis confirmed the cleavage of an asymmetrical azo bond and liberation of products such as 2-naphthol during degradation [86]. Herein, Anchan et al. (2019) prepared magnetic FeO-NPs ( $\gamma$ and $\alpha-\mathrm{Fe}_{2} \mathrm{O}_{3}$ phases) by using the leaf extract of Peltophorum pterocarpum for the first time. As-synthesized rod-like FeO-NPs were agglomerated due to the magnetic property of iron and witnessed in FE-SEM images where the average crystallite size was $16.99 \mathrm{~nm}$ with a specific surface area $\left(66.44 \mathrm{~m}^{2} / \mathrm{g}\right)$. The Fenton-like catalytic efficiency of FeO-NPs was satisfactorily fitted to a second-order model for the $90 \%$ degradation of methylene blue dye with a degradation constant of $0.0987 \mathrm{~L} / \mathrm{mg}$ min over $220 \mathrm{~min}$ [87].

Table 3. Synthesis of iron/iron oxide nanoparticles using different plant extract and its degradation efficiency.

\begin{tabular}{|c|c|c|c|c|c|c|}
\hline Plant Materials & MNPs & Size and Shape & Organic Dyes & $\begin{array}{c}\text { Catalytic } \\
\text { Reagents/Sunlight }\end{array}$ & $\begin{array}{c}\text { Degradation (\%) or Rate } \\
\text { of Reaction (k) }\end{array}$ & Ref. \\
\hline Camellia sinensis leaf & $\mathrm{nZVI} / \mathrm{Fe}^{0} \mathrm{NPs}$ & $\begin{array}{l}5 \text { to } 15 \mathrm{~nm}, \\
\text { spherical }\end{array}$ & $\begin{array}{l}\text { Bromothymol } \\
\text { blue }\end{array}$ & $\mathrm{H}_{2} \mathrm{O}_{2}$ & $0.1447 \mathrm{~min}^{-1}$ & [82] \\
\hline $\begin{array}{l}\text { Andean blackberry } \\
\text { leaf }\end{array}$ & $\mathrm{Fe}_{3} \mathrm{O}_{4} \mathrm{NPs}$ & $\begin{array}{l}54.5 \pm 24.6 \mathrm{~nm} \\
\text { spherical }\end{array}$ & $\mathrm{MB}, \mathrm{CR}, \mathrm{MO}$ & Sunlight & $\begin{array}{c}0.0105475,0.0043240 \text {, and } \\
0.0028930 \mathrm{~min}^{-1}\end{array}$ & [83] \\
\hline $\begin{array}{l}\text { Green, Oolong, and } \\
\text { black teas }\end{array}$ & FeNPs & $40-50 \mathrm{~nm}$ & MG & Adsorption & $81.6 \%, 75.6 \%$, and $67.1 \%$ & [84] \\
\hline $\begin{array}{l}\text { Cynara cardunculus } \\
\text { leaf }\end{array}$ & $\mathrm{Fe}_{3} \mathrm{O}_{4} \mathrm{NPs}$ & $\begin{array}{c}13.5 \mathrm{~nm}, \\
\text { Semi-spherical, } \\
\text { aggregated }\end{array}$ & MB & Adsorption & $>90 \%$ & [85] \\
\hline Grape leaf & $\mathrm{nZVI} / \mathrm{Fe}^{0} \mathrm{NPs}$ & $18-30 \mathrm{~nm}$ & Orange II & High temperature & $>92 \%$ & [86] \\
\hline $\begin{array}{c}\text { Peltophorum } \\
\text { pterocarpum leaf }\end{array}$ & $\begin{array}{c}\gamma \text { and } \\
\alpha-\mathrm{Fe}_{2} \mathrm{O}_{3} \mathrm{NPs}\end{array}$ & $16.99 \mathrm{~nm}$, rod-like & MB & Fenton & $90 \%$ & [87] \\
\hline Green tea leaf & FeNPs & $\begin{array}{l}\text { 130-270 } \mathrm{nm}, \\
\text { aggregated }\end{array}$ & MB & $\mathrm{NaBH}_{4}$ & $0.0404 \mathrm{~min}^{-1}$ & [88] \\
\hline $\begin{array}{l}\text { Amaranthus spinosus } \\
\text { leaf }\end{array}$ & FeO-NPs & $\begin{array}{l}91 \mathrm{~nm}, \\
\text { rhombohedral }\end{array}$ & $\mathrm{MO}$ andMB & Sunlight & $75 \pm 2 \%$ and $69 \pm 2 \%$ & [89] \\
\hline Wedelia urticifolia leaf & FeO-NPs & $70 \mathrm{~nm}, \mathrm{rod}$ & MB & Sunlight & $0.3299 \mathrm{~min}^{-1}$ & [90] \\
\hline Plantago major leaf & $\mathrm{FeO}-\mathrm{NPs}$ & $\begin{array}{l}\text { 4.6-30.6 nm, } \\
\text { Spherical }\end{array}$ & $\mathrm{MO}$ & $\mathrm{H}_{2} \mathrm{O}_{2}$ & $83.33 \%$ & [91] \\
\hline Pisum sativum peel & $\mathrm{Fe}_{3} \mathrm{O}_{4} \mathrm{NPs}$ & $\begin{array}{l}\text { 20-30 nm, } \\
\text { spherical }\end{array}$ & MO & Adsorption & $96.2 \%, 100 \mathrm{mg} / \mathrm{L}$ & [92] \\
\hline Citrus paradise peel & $\begin{array}{c}\mathrm{Fe}_{3} \mathrm{O}_{4}, \alpha-\mathrm{Fe}_{2} \mathrm{O}_{3} \\
\text { and } \gamma-\mathrm{Fe}_{2} \mathrm{O}_{3} \mathrm{NPs}\end{array}$ & $\begin{array}{l}\text { 28-32, spherical } \\
\text { aggregating }\end{array}$ & $\mathrm{MR}, \mathrm{MB}$ and $\mathrm{MO}$ & Adsorption & $\begin{array}{c}96.65 \%, 50 \mathrm{mg} / \mathrm{L} ; 80.76 \% \\
10 \mathrm{mg} / \mathrm{L} ; \text { and } 89.64 \% \\
10 \mathrm{mg} / \mathrm{L}\end{array}$ & [93] \\
\hline $\begin{array}{l}\text { Hibiscus sabdariffa } \\
\text { flower }\end{array}$ & FeO-NPs & $\begin{array}{l}10-100 \mathrm{~nm}, \\
\text { spherical }\end{array}$ & CR & UV-light & $96.1 \%, 100 \mathrm{mM}, \mathrm{pH} 4$ & [94] \\
\hline Ruellia tuberose leaf & FeO-NPs & $\begin{array}{c}52.78 \mathrm{~nm}, \\
\text { hexagonal } \\
\text { nanorods with } \\
\text { agglomeration }\end{array}$ & Crystal violet & Sunlight & $80 \%$ & [95] \\
\hline Ficus carica fruit & $\gamma-\mathrm{Fe}_{2} \mathrm{O}_{3}$ & 4-6 nm, spherical & 4-Nitrophenol & $\mathrm{NaBH}_{4}$ & $49.975 \times 10^{-3} \mathrm{~min}^{-1}$ & [96] \\
\hline
\end{tabular}


Lin et al. (2015) demonstrated the fabrication of iron-based nanoparticles (FeNPs) under various atmospheric gases $\left(\mathrm{N}_{2}, \mathrm{O}_{2}\right.$, and air) to understand how atmospheres impacting on the reactivity of Fe NPs and the prepared FeNPs were further used for the degradation of MB. It was observed that the change in morphology of FeNPs before and after reaction with MB is confirmed by the results of SEM and FTIR. Furthermore, the data were fitted well to the pseudo-second-order adsorption and pseudo-first-order reduction models, confirming that the degraded products were benzothiazole and the remediation of MB by an adsorption and reduction [88] method. Muthukumar and Matheswaran (2015) reported Amaranthus spinosus leaf extract mediated the green synthesis of FeONPs. The synthesized NPs were spherical in size, $91 \mathrm{~nm}$, and had a rhombohedral phase structure. The photocatalytic color removal efficiency for $\mathrm{MO}(75 \pm 2 \%)$ was higher than $\mathrm{MB}(69 \pm 2 \%)$ using as-synthesized FeO-NPs under sunlight irradiation, and subsequently, its catalytic activity was compared with chemically synthesized FeO-NPs [89]. More recently, Rather and Sundarapandian have synthesized rod-shaped magnetic iron oxide nanostructures by green methods using the aqueous leaf extract of Wedelia urticifolia and characterized by UV-Vis spectroscopy, FTIR, XRD, particle size analyzer, and TEM. Characterization techniques revealed that the rod-shaped nanostructures were monodispersed and weakly ferromagnetic with an average length of $70 \mathrm{~nm}$ and a width range of $15-20 \mathrm{~nm}$, and they possess strong ability to degrade methylene blue dye [90]. Another study by Lohrasbi et al. (2020) successfully synthesized FeO-NPs via an ecofriendly method using aqueous leaf extract of Plantago major and evaluated their ability to remove dyes. The synthesized $\mathrm{FeO}-\mathrm{NPs}$ were characterized by the different analytical techniques, including the vibratory sample magnetometer and thermogravimetric analysis. As-synthesized FeO-NPs were spherical in shape with diameters in the range of $4.6-30.6 \mathrm{~nm}$ and efficiently removed $83.33 \%$ of methyl orange with $\mathrm{H}_{2} \mathrm{O}_{2}$ in a $6 \mathrm{~h}$ process [91]. Prasad et al. (2017) has developed a facile and ecofriendly method for the synthesis of $\mathrm{Fe}_{3} \mathrm{O}_{4}$ magnetic nanoparticles using an aqueous extract of Pisum sativum peels. After synthesis, the $\mathrm{Fe}_{3} \mathrm{O}_{4} \mathrm{NPs}$ were characterized by FTIR, XRD, TEM, and Raman spectroscopy. The results confirmed the ferromagnetic nature of $\mathrm{Fe}_{3} \mathrm{O}_{4} \mathrm{NPs}$, and the spherical size varies between 20 and $30 \mathrm{~nm}$ with agglomeration. Furthermore, the catalytic properties of $\mathrm{Fe}_{3} \mathrm{O}_{4} \mathrm{NPs}$ for the degradation of methyl orange (MO) dye in aqueous solution were investigated by UV-visible spectroscopy [92]. Recently, Kumar et al. (2020) introduced the biosynthesis of iron oxide nanoparticles using non-edible peel extracts from Citrus paradisi. The DLS and TEM analysis confirms that the FeONPs are mostly spherical shape, aggregating in nature with an average size of 28 to $32 \mathrm{~nm}$, whereas XRD analysis confirmed the co-existence of a mixture of $\mathrm{Fe}_{3} \mathrm{O}_{4}$, $\alpha-\mathrm{Fe}_{2} \mathrm{O}_{3}$, and $\gamma-\mathrm{Fe}_{2} \mathrm{O}_{3}$ nanoparticle. Prepared iron nanoparticles exhibited antioxidant activity against 1, 1-diphenyl-2-picrylhydrazyl and the removal of MR $(96.65 \%, 50 \mathrm{mg} / \mathrm{L})$, MB $(80.76 \%, 10 \mathrm{mg} / \mathrm{L})$, and MO $(89.64 \%, 10 \mathrm{mg} / \mathrm{L})$ dyes [93]. The biofabrication of Fe nanoparticles using Hibiscus sabdariffa (Roselle) flower extract is an eco-friendly and costeffective protocol that was first reported by Alshehri et al. in 2017. Hibiscus sabdariffa is a strongly basic dye with a large number of medicinal applications and is used for a variety of diagnostic purposes. From the transmission TEM analysis, it is clear that the particles are mainly spherical with a size of $100 \mathrm{~nm}$. Then, the synthesized FeO-NPs were utilized as a photocatalyst for the degradation of the toxic organic dye $C R$, and maximum dye degradation efficiency was observed at a $\mathrm{pH}$ of 4 with $15 \mathrm{mg}$ of Fe nanoparticles. A degradation rate of $96.1 \%$ was achieved at a dye concentration of $100 \mathrm{mM}$ at room temperature $\left(30^{\circ} \mathrm{C}\right)$ [94]. In another study, FeONPs were synthesized with an aqueous extract of Ruellia tuberosa leaf; further characterization of FeONPs was performed using UV-vis spectroscopy, showing a visible peak at $405 \mathrm{~nm}$, and TEM analysis revealed $52.78 \mathrm{~nm}$ hexagonal nanorods with agglomeration. FeONPs showed higher antibacterial activity against Escherichia coli, Klebsiella pneumoniae, and lesser antibacterial activity against Staphylococcus aureus. The photocatalytic ability of the synthesized FeONPs was demonstrated by the degrading crystal violet dye under solar irradiation up to 80\% [95]. Recently, Kumar et al. (2021) reported a simple, one-pot and green method for the biosynthesis of single-phase maghemite 
$\left(\gamma-\mathrm{Fe}_{2} \mathrm{O}_{3}\right)$ nanoparticles using an aqueous fruit extract from Ficus carica. The XRD pattern confirmed the purity of $\gamma-\mathrm{Fe}_{2} \mathrm{O}_{3}$ nanoparticles, while TEM micrographs confirmed the formation of spherical and 4-6 nm sized nanoparticles. In addition, $\gamma-\mathrm{Fe}_{2} \mathrm{O}_{3} \mathrm{NPs}$ showed considerable antioxidant activity against DPPH and catalytic activity for the reduction of 4-nitrophenol $\left(49.975 \times 10^{-3} \mathrm{~min}^{-1}\right)$ using $\mathrm{NaBH}_{4}$ [96]. Such desired advantages make $\mathrm{Fe} / \mathrm{FeO}-\mathrm{NPs}$ suitable for various bioengineering purposes and catalysis applications.

\section{Mechanism for Degradation of Organic Dyes Using Nanoparticles}

Photocatalytic activity is the ability of a material to create an electron-hole pair as a result of exposure to solar radiation. The photocatalytic activity of phytochemicals modified metal nanoparticles has been studied extensively because of its potential use in sterilization, sanitation, and remediation under exposure to solar/visible/ultraviolet. It is also applied as an anti-soiling, antifungal, anti-bacterial, and antiviral agent, in air purification and deodorizing, and in wastewater treatment. The ability of gold, silver, and iron/iron oxide nanoparticles as a photocatalyst for the remediation of organic dyes and wastewater treatment is extensively studied [11]. The mechanism of catalysis in the presence of $\mathrm{NaBH}_{4}$ and MNPs/Au/Ag/FeNPs can be described as an electron transfer process from donor $\mathrm{NaBH}_{4}$ to an acceptor dye. MNPs act as an electron relay and trigger the movement of the electron from the $\mathrm{BH}_{4}{ }^{-}$ion (donor $\mathrm{B}_{2} \mathrm{H}_{4} / \mathrm{BH}_{4}{ }^{-}$) to the organic dye (acceptor) and thus cause a reduction of the dye. The $\mathrm{BH}_{4}{ }^{-}$ion was simultaneously adsorbed on the surface of NPs, and thus, electron transfer occurs from the $\mathrm{BH}_{4}{ }^{-}$ion to the organic dye through NPs [97].

Using solar energy is an interesting aspect in photocatalytic technologies. Solar photocatalysis has become an important area of research in which sunlight is the source of illumination to perform various photocatalytic reactions to different kinds of dyes. In the literature, research on photocatalysis reveals that photocatalytic activity can be strongly dependent on the crystallographic structure, morphology, and particle size [98]. The photocatalytic mechanism of MNPs/Au/Ag/FeNPs can be schematically illustrated in Figure 7.

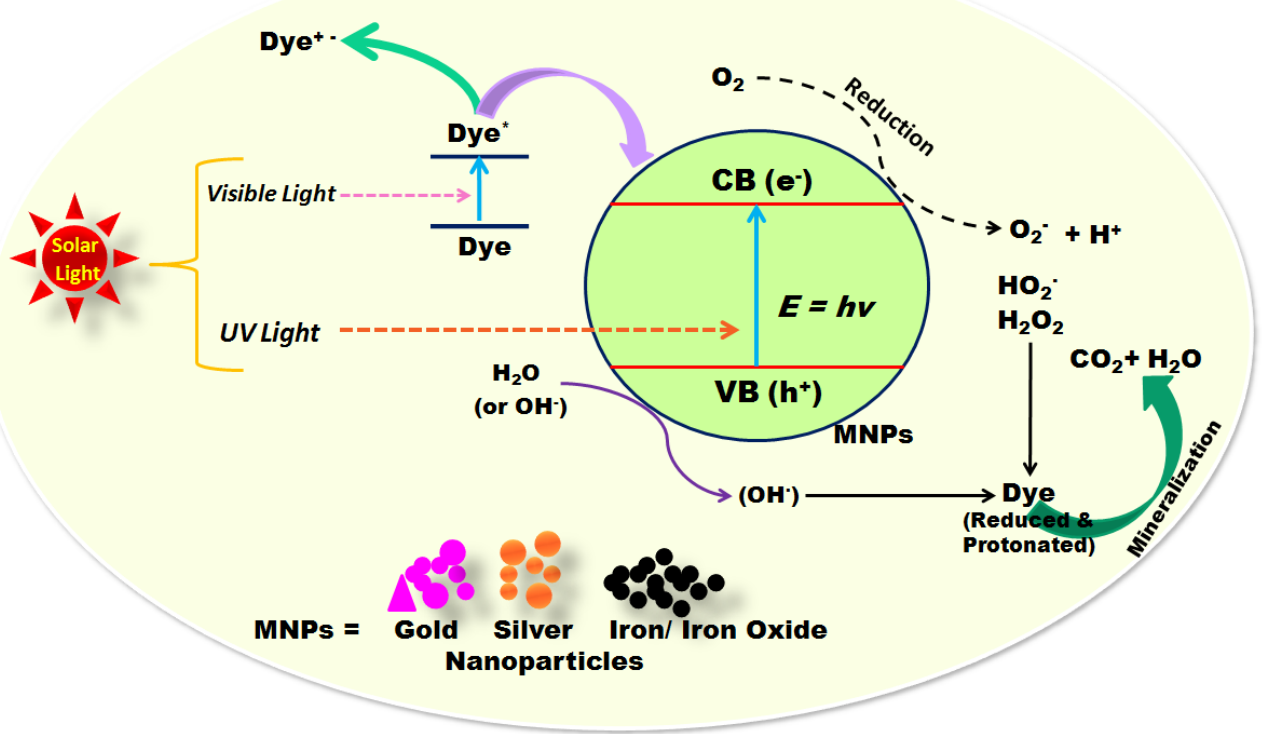

Figure 7. General mechanism for the photocatalytic degradation of different dyes using various nanoparticles of gold, silver and iron/iron oxide.

Although direct photocatalysis is thermodynamically feasible but not common, indirect photocatalysis is another approach that explains the process of photocatalysis, in which the excitons formed do not react directly with the dye molecules. Instead, they react with the exciton trapping molecules adsorbed on the catalyst surface to form free radicals, which 
then react with the dye molecules [99]. During the photocatalytic process, the absorption of photons by the nanophoto catalysts leads to the excitations of electrons from the valance band (VB) to the conduction band (CB), generating electron $\left(\mathrm{e}^{-}\right) /$hole $\left(\mathrm{h}^{+}\right)$pairs. The holes can react to the $\mathrm{H}_{2} \mathrm{O}$ molecule and transform to hydroxyl radical $(\bullet \mathrm{OH})$ and hydronium ions $\left(\mathrm{H}^{+}\right)$, as depicted in Equation (7); the holes may also react with the surface-adsorbed hydroxide ions to form hydroxyl radicals as in Equation (8). The excited electrons react with oxygen molecules and hydronium ions to form hydrogen peroxide, which can further dissociate in the presence of oxygen to form hydroxyl ions, as depicted in Equations (9)-(11). Eventually, the transformed active species and also $\mathrm{h}^{+}$could react effectively to the organic dye. The electrons in the conduction band are captured by oxygen molecules dissolved in the suspension and in the valance band captured by $\mathrm{OH}^{-}$or $\mathrm{H}_{2} \mathrm{O}$ species absorbed on the surface of the catalyst to produce the hydroxyl radicals $(\bullet \mathrm{OH})$. Then, these hydroxyl radicals oxidize the pollutants/dye to small inorganic molecules [100,101]. In addition, the large surface area of MNPs can cause desorption of the colorless final product.

The photocatalytic degradation process may be represented by the following reaction:

$$
\begin{gathered}
\text { MNPs }+\mathrm{h} v \rightarrow \mathrm{h}^{+}+\mathrm{e}^{-} \text {(photogeneration of excitons) } \\
\mathrm{H}_{2} \mathrm{O}+\mathrm{h}^{+} \rightarrow \bullet \mathrm{OH}+\mathrm{H}^{+} \\
\mathrm{OH}^{-}+\mathrm{h}^{+} \rightarrow \bullet \mathrm{OH} \\
\mathrm{e}^{-}+\mathrm{O}_{2} \rightarrow \bullet \mathrm{O}_{2}^{-} \\
\bullet \mathrm{O}_{2}^{-}+\mathrm{H}^{+} \rightarrow \bullet \mathrm{OOH} / \mathrm{H}_{2} \mathrm{O}_{2} \\
\mathrm{H}_{2} \mathrm{O}_{2} \rightarrow \bullet \mathrm{OH}+\bullet \mathrm{OH} \\
\text { Dye }+\mathrm{h} v \rightarrow \text { Dye }^{*}
\end{gathered}
$$

Dye ${ }^{*}+\mathrm{O}_{2}$ or $\bullet \mathrm{OH}$ or $\bullet \mathrm{O}_{2}{ }^{-} \rightarrow$ (unstable intermediate $) \rightarrow$ degradation products $\left(\mathrm{CO}_{2}+\mathrm{H}_{2} \mathrm{O}\right)$

\section{Toxicological Issue}

The toxicological risks of MNPs have attracted widespread attention, and many studies have been published that have contributed to understanding MNPs-induced toxicity on different in vitro and in vivo living systems. The applicability of nanostructured materials involves the development of products into industrial materials, medicine, nutrition, textiles, cosmetics, electronics, and energy, and it offers new opportunities for social and economic development. MNPs easily enter into the human body through skin uptake, inhalation, and intravenous injection due to their small particle sizes; there is a serious negative impact on the environment, and ecological systems should be carefully evaluated [102,103]. The interaction of MNPs with proteins, nucleic acid, and cell membrane contributes to the toxicity. It has already been reported that MNPs toxicity is related to the generation of reactive oxygen species and causes multiple abnormal physiological effects, such as DNA damage, membrane damage, cell proliferation inhibition, inflammation, mitochondrial dysfunction, cell apoptosis, activation of antioxidant enzymes, depletion of antioxidant molecules (e.g., glutathione), binding and disabling of proteins, and others. Several major questions remain to be answered: (1) the toxic contribution from the ionic form versus the nano-form; and (2) the key enzymes and signaling pathways responsible for the toxicity.

Silver is an ancient antibiotic that has found many new uses due to its unique properties at the nanoscale. Due to its presence in many consumer products, the toxicity of nanosilver has become a hot topic. AgNPs can decrease cell proliferation and chemotaxis of the human mesenchymal stem cells, increase cytotoxicity and oxidative stress of the human hepatoma HepG2 cells, and have several other adverse effects [103]. Experimental evidence on human monocytes by Wang et al. has clearly confirmed that the chemical transformations of particulate silver from the elemental silver $\left(\mathrm{Ag}^{0}\right)$ to $\mathrm{Ag}^{+}$ions, $\mathrm{Ag}_{2} \mathrm{O}$, and then to $\mathrm{Ag}_{2} \mathrm{~S}$ - species are the main cause of toxicity. Therefore, the toxicity of nanosilver is closely related to the release of $\mathrm{Ag}^{+}$[104]. The toxicity of MNPs is caused by the slow 
release of $\mathrm{M}^{\mathrm{n}+}$ ions, due to surface oxidation, other surface reactions, and the dissolution of MNPs in a biological or environmental medium. The toxicity of MNPs strongly depends on their size, shape, and doses. Smaller particles have a higher toxicity than larger particles, due to their larger surface area availability and thus a stronger ion release. In addition, they can more easily cross the biological barriers in living organisms, such as the blood-brain or the blood-testes barrier and cause cellular dysfunction [105]. The small size and variable properties of $\mathrm{Ag} / \mathrm{Au}$ nanoparticles are suggested to be hazardous to the environment due to their irreversibly binding to B-form DNA [106]. The accumulation of Ag nanoparticles in various organs (lungs, kidneys, brain, liver, and testes) has been evidenced in animal studies [107]. The structure and properties of gold nanoparticles make them useful for a wide array of biological applications, and studies show that cationic gold particles are moderately toxic, while anionic particles are quite nontoxic [108]. The cytotoxicity of TPPMS/TPPTS-modified gold nanoparticles depended primarily on their size and not on the chemistry of ligand. The 1-2 nm particles were highly toxic, and the smaller gold compounds (Tauredon) and larger $15 \mathrm{~nm}$ gold colloids/AuNPs were comparatively nontoxic (100 fold and 60-fold higher concentrations), irrespective of the cell type tested [109]. The cell/tissue type, administration pathway, surface morphology, presence of protein corona, surface charge density, chemical composition, and charge of surface coating seem to be critical factors for Fe/FeONPs toxicity; usually, bare nanoparticles are more toxic than the organically coated ones. According to previous in vitro and in vivo studies, low toxicity by Fe/FeONPs is suspected [110]. Hoskins et al. [111] determined that $\mathrm{Nano}-\mathrm{Fe}_{3} \mathrm{O}_{4}$ coated with poly(ethylenimine), which had a higher surface charge than nano- $\mathrm{Fe}_{3} \mathrm{O}_{4}$-poly(ethylenimine)-poly(ethylene glycol), exhibited greater cytotoxicity and ROS formation in human SH-SY5Y, MCF-7, and U937 cell lines, and it is also responsible for the formation of ROS and lipid peroxidation. To some extent, the morphology, charge, type of coating, and surface areas are strongly related to the nanotoxicity of MNPs in terms of cellular uptake and immune response.

\section{Conclusions}

In this review article, we have discussed the most commonly used gold, silver, and iron/iron oxide nanoparticles in wastewater treatment. All metallic nanoparticles were synthesized using different plant materials as reductants and a stabilizer without using fancy experimental equipment. Its beneficial effects include the solar light-harvesting potential for the degradation of organic dyes, shorter reaction time, low-cost reagents, and possible environmentally friendly alternatives to toxic chemical methods. The use of plant extracts is an alternative to explore the control in the shape and broad size distributions, and it is also attractive for the scaling up of metallic nanomaterials. Photocatalysis in the presence of gold, silver, and iron/iron oxide nanoparticles favors the ecofriendly remediation of organic dye pollutants in wastewater. The photocatalytic activity of smaller and spherical nanoparticles was higher as compared to larger and triangular nanoparticles. The phytochemically functionalized surface of nanoparticles creates the stability and biocompatibility. Meanwhile, the nanoparticles showed efficient photocatalytic activity against organic dyes and support the use of renewable energy for environmental protection. Green synthesized nanoparticles can be used as a photocatalyst/catalyst in industries and water purification.

Funding: This research received no external funding.

Institutional Review Board Statement: No application.

Informed Consent Statement: No application.

Acknowledgments: This scientific work has been funded by the TATA College, Kolhan University, India.

Conflicts of Interest: The authors declare that there is no conflict of interests regarding the publication of this article. 


\section{References}

1. Sharma, V.K.; Filip, J.; Zboril, R.; Varma, R.S. Natural inorganic nanoparticles-Formation, fate, and toxicity in the environment. Chem. Soc. Rev. 2015, 44, 8410-8423. [CrossRef] [PubMed]

2. Stark, W.J.; Stoesset, P.R.; Wohlleben, W.; Hafner, A. Industrial applications of nanoparticles. Chem. Soc. Rev. 2015, 44, 5793-5805. [CrossRef] [PubMed]

3. Soenen, S.J.; Parak, W.J.; Rejman, J.; Manshian, B. (Intra)cellular stability of inorganic nanoparticles: Effects on cytotoxicity, particle functionality, and biomedical applications. Chem. Rev. 2015, 115, 2109-2135. [CrossRef] [PubMed]

4. Talebzadeh, S.; Queffelec, C.; Knight, D.A. Surface modification of plasmonic noble metal-metal oxide core-shell nanoparticles. Nanoscale Adv. 2019, 1, 4578-4591. [CrossRef]

5. Virkutyte, J.; Varma, R.S. Green synthesis of metal nanoparticles: Biodegradable polymers and enzymes in stabilization and surface functionalization. Chem. Sci. 2011, 2, 837-846. [CrossRef]

6. Kumar, B.; Smita, K.; Debut, A.; Cumbal, L. Andean Sacha Inchi (Plukenetia volubilis L.) leaf-mediated synthesis of $\mathrm{Cu}_{2} \mathrm{O}$ nanoparticles: A Low-Cost Approach. Bioengineering 2020, 79, 54. [CrossRef]

7. Shankar, P.D.; Shobana, S.A.; Karuppusamy, I.; Pugazhendhi, A.; Ramkumar, V.S.; Arvindnarayan, S.; Kumar, G. A review on the biosynthesis of metallic nanoparticles (gold and silver) using bio-components of microalgae: Formation mechanism and applications. Enzym. Microb. Technol. 2016, 95, 28-44. [CrossRef]

8. Nasrollahzadeh, M.; Yek, S.M.-G.; Motahharifar, N.; Gorab, M.G. Recent Developments in the Plant-Mediated Green Synthesis of Ag-Based Nanoparticles for Environmental and Catalytic Applications. Chem. Rec. 2019, 19, 2436-2479. [CrossRef]

9. Rahman, A.; Lin, J.; Jaramillo, F.E.; Bazylinski, D.A.; Jeffryes, C.; Dahoumane, S.A. In Vivo Biosynthesis of Inorganic Nanomaterials Using Eukaryotes-A Review. Molecules 2020, 25, 3246. [CrossRef]

10. Saha, B.; Das, S.; Saikia, J.; Das, G. Preferential and enhanced adsorption of different dyes on iron oxide nanoparticles: A comparative study. J. Phys. Chem. C 2011, 115, 8024-8033. [CrossRef]

11. Kumar, B.; Smita, K.; Kumar, B. Phytochemical functionalized metal nanocatalyst (Ag, Au, Fe, Zn and Pd) for remediation of organic dyes. In Advances in Chemistry Research; Taylor, J.C., Ed.; Nova Science Publishers: Hauppauge, NY, USA, 2017; Chapter 3, Volume 37, pp. 87-120.

12. Lam, S.-M.; Sin, J.-C.; Abdullah, A.Z.; Mohamed, A.R. Degradation of wastewaters containing organic dyes photocatalysed by zinc oxide: A review. Desalination Water Treat. 2012, 41, 131-169. [CrossRef]

13. Sharma, M.; Jain, T.; Singh, S.; Pandey, O.P. Photocatalytic degradation of organic dyes under UV-Visible light using capped ZnS nanoparticles. Sol. Energy 2012, 86, 626-633. [CrossRef]

14. Safavi, A.; Momeni, S. Highly efficient degradation of azo dyes by palladium/ hydroxyapatite/ $\mathrm{Fe}_{3} \mathrm{O}_{4}$ nanocatalyst. J. Hazard. Mater. 2012, 201-202, 125-131. [CrossRef]

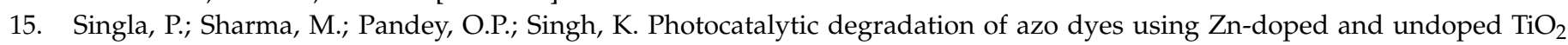
nanoparticles. Appl. Phys. A 2014, 116, 371-378. [CrossRef]

16. Touati, A.; Hammedi, T.; Najjar, W.; Ksibi, Z.; Sayadi, S. Photocatalytic degradation of textile wastewater in presence of hydrogen peroxide: Effect of cerium doping titania. J. Ind. Eng. Chem. 2016, 35, 36-44. [CrossRef]

17. Koe, W.S.; Lee, J.W.; Chong, W.C.; Pang, Y.L.; Sim, L.C. An overview of photocatalytic degradation: Photocatalysts, mechanisms, and development of photocatalytic membrane. Environ. Sci. Pollut. Res. 2020, 27, 2522-2565. [CrossRef] [PubMed]

18. Khalid, N.R.; Majid, A.; Tahir, M.B.; Niaz, N.A.; Khalid, S. Carbonaceous- $\mathrm{TiO}_{2}$ nanomaterials for photocatalytic degradation of pollutants: A review. Ceram. Int. 2017, 43, 14552-14571. [CrossRef]

19. Wood, R.W. On a remarkable case of uneven distribution of light in a diffraction grating spectrum. Proc. Phys. Soc. Lond. 1902, 18, 269-275. [CrossRef]

20. Homola, J.; Yee, S.S.; Gauglitz, G. Surface Plasmon Resonance Sensors: Review. Sens. Actuators B 1999, 54, 3-15. [CrossRef]

21. Raliya, R.; Saharan, V.; Dimkpa, C.; Biswas, P. Nanofertilizer for Precision and Sustainable Agriculture: Current State and Future Perspectives. J. Agric. Food Chem. 2018, 669, 6487-6503. [CrossRef]

22. Kang, H.; Buchman, J.T.; Rodriguez, R.S.; Ring, H.L.; He, J.; Bantz, K.C.; Haynes, C.L. Stabilization of Silver and Gold Nanoparticles: Preservation and Improvement of Plasmonic Functionalities. Chem. Rev. 2019, 119, 664-699. [CrossRef]

23. Cortie, M.B.; McDonagh, A.M. Synthesis and Optical Properties of Hybrid and Alloy Plasmonic Nanoparticles. Chem. Rev. 2011, 111, 3713-3735. [CrossRef]

24. Arinze, E.S.; Qiu, B.; Nyirjesy, G.; Thon, S.M. Plasmonic Nanoparticle Enhancement of Solution-Processed Solar Cells: Practical Limits and Opportunities. ACS Photonics 2016, 3, 158-173. [CrossRef]

25. Kumar, B.; Smita, K.; Debut, A.; Cumbal, L. Utilization of Persea americana (Avocado) oil for the synthesis of gold nanoparticles in sunlight and evaluation of antioxidant and photocatalytic activities. Environ. Nanotechnol. Monit. Manag. 2018, 10, $231-237$.

26. Kong, F.Y.; Zhang, J.W.; Li, R.F.; Wang, Z.X.; Wang, W.J.; Wang, W. Unique roles of gold nanoparticles in drug delivery, targeting and imaging applications. Molecules 2017, 22, 1445. [CrossRef] [PubMed]

27. Sarina, S.; Waclawik, E.R.; Zhu, H. Photocatalysis on supported gold and silver nanoparticles under ultraviolet and visible light irradiation. Green Chem. 2013, 15, 1814-1833. [CrossRef]

28. Kumar, B.; Smita, K.; Cumbal, L.; Debut, A. Extracellular biofabrication of gold nanoparticles by using Lantana camara berry extract. Inorg. Nano-Met. Chem. 2017, 47, 138-142. [CrossRef] 
29. Kumar, B.; Smita, K.; Cumbal, L. Phytosynthesis of gold nanoparticles using Andean Aj1' (Capsicum baccatum L.). Cogent Chem. 2015, 1, 1120982. [CrossRef]

30. Paul, B.; Bhuyan, B.1.; Purkayastha, D.D.; Dhar, S.S. Photocatalytic and antibacterial activities of gold and silver nanoparticles synthesized using biomass of Parkia roxburghii leaf. J. Photochem. Photobiol. B Biol. 2016, 154, 1-7. [CrossRef] [PubMed]

31. Baruah, D.; Goswami, M.; Yadav, R.N.S.; Yadav, A.; Das, A.M. Biogenic synthesis of gold nanoparticles and their application in photocatalytic degradation of toxic dyes. J. Photochem. Photobiol. B Biol. 2018, 186, 51-58. [CrossRef]

32. Desai, M.P.; Sangaokar, G.M.; Pawar, K.D. Kokum fruit mediated biogenic gold nanoparticles with photoluminescent, photocatalytic and antioxidant activities. Process. Biochem. 2018, 70, 188-197. [CrossRef]

33. Kumar, B.; Smita, K.; Cumbal, L. Biofabrication of nanogold from the flower extracts of Lantana camara. IET Nanobiotechnol. 2016, 10, 154-157. [CrossRef]

34. Kumar, B.; Smita, K.; Cumbal, L.; Debut, A. One pot synthesis and characterization of gold nanocatalyst using Sacha inchi (Plukenetia volubilis) oil: Green approach. J. Photochem. Photobiol. B Biol. 2016, 158, 55-60. [CrossRef] [PubMed]

35. Mythili, R.; Selvankumar, T.; Srinivasan, P.; Sengottaiyan, A.; Sabastinraj, J.; Ameen, F.; Al-Sabri, A.; Kamala-Kannan, S.; Govarthanan, M.; Kim, H. Biogenic synthesis, characterization and antibacterial activity of gold nanoparticles synthesised from vegetable waste. J. Mol. Liq. 2018, 262, 318-321. [CrossRef]

36. Devi, H.S.; Singh, N.R.; Singh, H.P.; Singh, T.D. Facile synthesis of biogenic gold nanocatalyst for efficient degradation of organic pollutants. J. Environ. Chem. Eng. 2015, 3, 2042-2049. [CrossRef]

37. Mata, R.; Bhaskaran, A.; Sadras, S.R. Green-synthesized gold nanoparticles from Plumeria alba flower extract to augment catalytic degradation of organic dyes and inhibit bacterial growth. Particuology 2016, 24, 78-86. [CrossRef]

38. Singh, R.K.; Behera, S.S.; Singh, K.R.; Mishra, S.; Panigrahi, B.; Sahoo, T.R.N.; Parhi, P.J.K.; Mandal, D. Biosynthesized gold nanoparticles as photocatalysts for selective degradation of cationic dye and their antimicrobial activity. J. Photochem. Photobiol. A Chem. 2020, 400, 112704. [CrossRef]

39. Naik, G.K.; Mishra, P.M.; Parida, K. Green synthesis of $\mathrm{Au} / \mathrm{TiO}_{2}$ for effective dye degradation in aqueous system. Chem. Eng. J. 2013, 229, 492-497. [CrossRef]

40. Umamaheswari, C.; Lakshmanan, A.; Nagarajan, N.S. Green synthesis, characterization and catalytic degradation studies of gold nanoparticles against congo red and methyl orange. J. Photochem. Photobiol. B Biol. 2018, 178, 33-39. [CrossRef] [PubMed]

41. Bogireddy, N.K.R.; Anand, K.K.H.; Mandal, B.K. Gold nanoparticles-Synthesis by Sterculia acuminata extract and its catalytic efficiency in alleviating different organic dyes. J. Mol. Liq. 2015, 211, 868-875. [CrossRef]

42. Paul, B.; Bhuyan, B.; Purkayastha, D.D.; Dey, M.; Dhar, S.S. Green synthesis of gold nanoparticles using Pogestemon benghalensis (B) O. Ktz. leaf extract and studies of their photocatalytic activity in degradation of methylene blue. Mater. Lett. 2015, 148, 37-40. [CrossRef]

43. Francis, S.; Joseph, S.; Koshy, E.P.; Mathew, B. Green synthesis and characterization of gold and silver nanoparticles using Mussaenda glabrata leaf extract and their environmental applications to dye degradation. Environ. Sci. Pollut. Res. 2017, 24, 17347-17357. [CrossRef] [PubMed]

44. Ali, S.; Ali, H.; Siddique, M.; Gulab, H.; Haleem, M.A.; Ali, J. Exploring the biosynthesized gold nanoparticles for their antibacterial potential and photocatalytic degradation of the toxic water wastes under solar light illumination. J. Mol. Struct. 2020, 1215, 128259. [CrossRef]

45. Kumar, I.; Mondal, M.; Meyappan, V.; Sakthivel, N. Green one-pot synthesis of gold nanoparticles using Sansevieria roxburghiana leaf extract for the catalytic degradation of toxic organic pollutants. Mater. Res. Bull. 2019, 117, 18-27. [CrossRef]

46. Vinay, S.P.; Nagaraju, G.; Chandrappa, C.P.; Chandrasekhar, N. Hydrothermal synthesis of gold nanoparticles using spider cobweb as novel biomaterial: Application to photocatalytic. Chem. Phys. Lett. 2020, 748, 137402. [CrossRef]

47. Chokkalingam, M.; Rupa, E.J.; Huo, Y.; Mathiyalagan, R.; Anandapadmanaban, G.; Ahn, J.C.; Park, J.K.; Lu, J.; Yang, D.C. Photocatalytic degradation of industrial dyes using Ag and Au nanoparticles synthesized from Angelica gigas ribbed stem extracts. Optik 2019, 185, 1213-1219. [CrossRef]

48. Sastry, M.; Patil, V.; Sainkar, S.R. Electrostatically controlled diffusion of carboxylic acid derivatized silver colloidal particles in thermally evaporated fatty amine films. J. Phys. Chem. B 1998, 102, 1404-1410. [CrossRef]

49. Kumar, B.; Smita, K.; Cumbal, L.; Debut, A.; Pathak, R.N. Sonochemical Synthesis of Silver Nanoparticles Using Starch: A Comparison. Bioinorg. Chem. Appl. 2014, 2014, 784268. [CrossRef]

50. Kumar, B.; Smita, K.; Cumbal, L.; Debut, A. Phytosynthesis of silver nanoparticles using andean cabbage: Structural Characterization and its Application. Mater. Today Proc. 2020, 21, 2079-2086. [CrossRef]

51. Kumar, B.; Vizuete, K.S.; Sharma, V.; Debut, A.; Cumbal, L. Ecofriendly synthesis of monodispersed silver nanoparticles using Andean Mortiño berry as reductant and its photocatalytic activity. Vacuum 2019, 160, 272-278. [CrossRef]

52. Guzmán, K.; Kumar, B.; Vallejo, M.J.; Grijalva, M.; Debut, A.; Cumbal, L. Ultrasound-assisted synthesis and antibacterial activity of gallic acid-chitosan modified silver nanoparticles. Prog. Org. Coat. 2019, 129, 229-235. [CrossRef]

53. Kumar, B.; Smita, K.; Cumbal, L.; Debut, A. Sacha inchi (Plukenetia volubilis L.) oil for one pot synthesis of silver nanocatalyst: An ecofriendly approach. Ind. Crop. Prod. 2014, 58, 238-243. [CrossRef]

54. Sharma, P.; Pant, S.; Rai, S.; Yadav, B.; Dave, V. Green synthesis of silver nanoparticle capped with Allium cepa and their catalytic reduction of textile dyes: An ecofriendlyapproach. J. Polym.Environ. 2018, 26, 1795-1803. [CrossRef] 
55. Kumar, B.; Smita, K.; Cumbal, L. Biosynthesis of silver nanoparticles using Lantana camara flower extract and its application. J. Sol-Gel. Sci. Technol. 2016, 78, 285-292. [CrossRef]

56. Vizuete, K.S.; Kumar, B.; Guzmán, K.; Debut, A.; Shora, L.C. (Capparis petiolaris) fruit mediated green synthesis and application of silver nanoparticles. Green Process. Synth. 2017, 6, 23-30. [CrossRef]

57. Arunachalam, R.; Dhanasingh, S.; Kalimuthu, B.; Uthirappan, M.; Rose, C.; Mandal, A.B. Phytosynthesis of silver nanoparticles using Cocciniagrandis leaf extract and its application in the photocatalytic degradation. Colloids Surf. B Biointerfaces 2012, 94, 226-230. [CrossRef] [PubMed]

58. Kou, J.; Varma, R.S. Beet juice-induced green fabrication of plasmonic AgCl/Ag nanoparticles. ChemSusChem 2012, 5, $2435-2441$. [CrossRef] [PubMed]

59. Kumar, B.; Smita, K.; Cumbal, L.; Debut, A. Sacha inchi (Plukenetia volubilis L.) shell biomass for synthesis of silver nanocatalyst. J. Saudi Chem. Soc. 2017, 21, S293-S298. [CrossRef]

60. Kumar, B.; Smita, K.; Cumbal, L.; Debut, A.; Camacho, J.; Hernández-Gallegos, E.; Chávez-López, M.d.; Grijalva, M.; Angulo, Y.; Rosero, G. Pomosynthesis and Biological activity of Silver Nanoparticles using Passiflora tripartita fruit extracts. Adv. Mater. Lett. 2015, 6, 127-132. [CrossRef]

61. Vanaja, M.; Paulkumar, K.; Baburaja, M.; Rajeshkumar, S.; Gnanajobitha, G.; Malarkodi, C.; Sivakavinesan, M.; Annadurai, G. Degradation of methylene blue using biologically synthesized silver nanoparticles. Bioinorg. Chem. Appl. 2014, $2014,742346$. [CrossRef]

62. Varadavenkatesan, T.; Selvaraj, R.; Vinayagam, R. Phyto-synthesis of silver nanoparticles from Mussaenda erythrophylla leaf extract and their application in catalytic degradation of methyl orange dye. J. Mol. Liq. 2016, 221, 1063-1070. [CrossRef]

63. Kumar, B.; Smita, K.; Angulo, Y.; Cumbal, L. Valorization of Rambutan peel for the synthesis of silver-doped titanium dioxide $\left(\mathrm{Ag} / \mathrm{TiO}_{2}\right)$ nanoparticles. Green Process. Synth. 2016, 5, 371-377. [CrossRef]

64. Bordbar, M. Biosynthesis of Ag/almond shell nanocomposite as a cost-effective and efficient catalyst for degradation of 4nitrophenol and organic dyes. RSC Adv. 2017, 7, 180-189. [CrossRef]

65. MeenaKumari, M.; Philip, D. Degradation of environment pollutant dyes using phytosynthesized metal nanocatalysts. Spectrochim. Acta Part A Mol. Biomol. Spectrosc. 2015, 135, 632-638. [CrossRef] [PubMed]

66. Edison, T.N.J.I.; Lee, Y.R.; Sethuraman, M.G. Green synthesis of silver nanoparticles using Terminalia cuneata and its catalytic action in reduction of direct yellow-12 dye. Spectrochim. Acta Part A Mol. Biomol. Spectrosc. 2016, 161, 122-129. [CrossRef]

67. Kaviya, S.; Prasad, E. Biogenic synthesis of $\mathrm{ZnO}-\mathrm{Ag}$ nano custard apples for efficient photocatalytic degradation of methylene blue by sunlight irradiation. RSC Adv. 2015, 5, 17179-17185. [CrossRef]

68. Gupta, N.; Singh, H.P.; Sharma, R.K. Metal nanoparticles with high catalytic activity in degradation of methyl orange: An electron relay effect. J. Mol. Catal. A Chem. 2011, 335, 248-252. [CrossRef]

69. Veisi, H.; Azizi, S.; Mohammadi, P. Green synthesis of the silver nanoparticles mediated by Thymbra spicata extract and its application as a heterogeneous and recyclable nanocatalyst for catalytic reduction of a variety of dyes in water. J. Clean. Prod. 2018, 170, 1536-1543. [CrossRef]

70. Khodadadi, B. Hazelnut shell as a valuable bio-waste support for green synthesis of Ag NPs using Origanum vulgare leaf extract: Catalytic activity for reduction of methyl orange and Congo red. Iran. J. Catal. 2017, 7, 111-119.

71. Wang, L.; Lu, F.; Liu, Y.; Wu, Y.; Wu, Z. Photocatalytic degradation of organic dyes and antimicrobial activity of silver nanoparticles fast synthesized by flavonoids fraction of Psidium guajava L. leaves. J. Mol. Liq. 2018, 263, 187-192. [CrossRef]

72. Lateef, A.; Akande, M.A.; Ojo, S.A.; Folarin, B.I.; Gueguim-Kana, E.B.; Beukes, L.S. Paper wasp nest-mediated biosynthesis of silver nanoparticles for antimicrobial, catalytic, anticoagulant, and thrombolytic applications. 3 Biotech. 2016, 6, 140. [CrossRef] [PubMed]

73. Qing, W.; Chen, K.; Wang, Y.; Liu, X.; Lu, M. Green synthesis of silver nanoparticles by waste tea extract and degradation of organic dye in the absence and presence of $\mathrm{H}_{2} \mathrm{O}_{2}$. Appl. Surf. Sci. 2017, 423, 1019-1024. [CrossRef]

74. Raj, S.; Singh, H.; Trivedi, R.; Son, V. Biogenic synthesis of AgNPs employing Terminalia arjuna leaf extract and its efcacy towards catalytic degradation of organic dyes. Sci. Rep. 2020, 10, 9616. [CrossRef] [PubMed]

75. Vanaamudan, A.; Soni, H.; Sudhakar, P.P. Palm shell extract capped silver nanoparticles-As efficient catalysts for degradation of dyes and as SERS substrates. J. Mol. Liq. 2016, 215, 787-794. [CrossRef]

76. David, L.; Moldovan, B. Green Synthesis of biogenic silver nanoparticles for efficient catalytic removal of harmful organic dyes. Nanomaterials 2020, 10, 202. [CrossRef] [PubMed]

77. Patil, S.S.; Mali, M.G.; Tamboli, M.S.; Patil, D.R.; Kulkarni, M.V.; Yoon, H.; Kim, H.; Al-Deyab, S.S.; Yoon, S.S.; Kolekar, S.S.; et al. Green approach for hierarchical nanostructured Ag-ZnO and their photocatalytic performance under sunlight. Catal. Today 2016, 260, 126-134. [CrossRef]

78. Li, X.-Q.; Elliott, D.W.; Zhang, W.-X. Zero-Valent Iron Nanoparticles for Abatement of Environmental Pollutants: Materials and Engineering Aspects. Crit. Rev. Solid State Mater. Sci. 2006, 31, 111-122. [CrossRef]

79. Wu, W.; He, Q.; Jiang, C. Magnetic Iron Oxide Nanoparticles: Synthesis and Surface Functionalization Strategies. Nanoscale Res. Lett. 2008, 3, 397-415. [CrossRef]

80. Nagajyothi, P.C.; Vattikuti, S.V.P.; Devarayapalli, K.C.; Yoo, K.; Shim, J.; Sreekanth, T.V.M. Green synthesis: Photocatalytic degradation of textile dyes using metal and metal oxide nanoparticles-latest trends and advancements. Crit. Rev. Environ. Sci. Technol. 2020, 50, 2617-2723. [CrossRef] 
81. Frost, R.L.; Xi, Y.; He, H. Synthesis, characterization of palygorskite supported zero-valent iron and its application for methylene blue adsorption. J. Colloid Interface Sci. 2010, 341, 153-161. [CrossRef]

82. Hoag, G.E.; Collins, J.B.; Holcomb, J.L.; Hoag, J.R.; Nadagouda, M.N.; Varma, R.S. Degradation of bromothymol blue by "greener" nano-scale zero-valent iron synthesized using tea polyphenols. J. Mater. Chem. 2009, 19, 8671-8677. [CrossRef]

83. Kumar, B.; Smita, K.; Cumbal, L.; Debut, A.; Galeas, S.; Guerrero, V.H. Phytosynthesis and photocatalytic activity of magnetite $\left(\mathrm{Fe}_{3} \mathrm{O}_{4}\right)$ nanoparticles using the Andean blackberry leaf. Mater. Chem. Phys. 2016, 179, 310-315. [CrossRef]

84. Huang, L.; Weng, X.; Chen, Z.; Megharaj, M.; Naidu, R. Green synthesis of iron nanoparticles by various tea extracts: Comparative study of the reactivity. Spectrochim. Acta Part A Mol. Biomol. Spectrosc. 2014, 130, 295-301. [CrossRef] [PubMed]

85. Ruíz-Baltazar, Á.D.; Reyes-López, S.Y.; Mondragón-Sánchez, M.D.; Robles-Cortés, A.I.; Pérez, R. Eco-friendly synthesis of Fe ${ }_{3} \mathrm{O}_{4}$ nanoparticles: Evaluation of their catalytic, activity in methylene blue degradation by kinetic adsorption models. Results Phys. 2019, 12, 989-995. [CrossRef]

86. Luo, F.; Yang, D.; Chen, Z.; Megharaj, M.; Naidu, R. The mechanism for degrading Orange II based on adsorption and reduction by ion-based nanoparticles synthesized by grape leaf extract. J. Hazard. Mater. 2015, 296, 37-45. [CrossRef]

87. Anchan, S.; Pai, S.; Sridevi, H.; Varadavenkatesan, T.; Vinayagam, R.; Selvaraj, R. Biogenic synthesis of ferric oxide nanoparticles using the leaf extract of Peltophorum pterocarpum and their catalytic dye degradation potential. Biocatal. Agric. Biotechnol. 2019, 20, 101251. [CrossRef]

88. Lin, J.; Weng, X.; Jin, X.; Megharaj, M.; Naidu, R.; Chen, Z. Reactivity of iron-based nanoparticles by green synthesis under various atmospheres and their removal mechanism of methylene blue. RSC Adv. 2015, 5, 70874-70882. [CrossRef]

89. Muthukumar, H.; Matheswaran, M. Amaranthus spinosus leaf extract mediated FeO nanoparticles: Physicochemical traits, photocatalytic and antioxidant activity. ACS Sustain. Chem. Eng. 2015, 3, 3149-3156. [CrossRef]

90. Rather, M.Y.; Sundarapandian, S. Magnetic iron oxide nanorod synthesis by Wedelia urticifolia(Blume) DC. leaf extract for methylene blue dye degradation. Appl. Nanosci. 2020, 10, 2219-2227. [CrossRef]

91. Lohrasbi, S.; Kouhbanani, M.A.J.; Beheshtkhoo, N.; Ghasemi, Y.; Amani, A.M.; Taghizadeh, S. Green synthesis of iron nanoparticles using Plantago major leaf extract and their application as a catalyst for the decolorization of azo dye. BioNanoScience 2019, 9, 317-322. [CrossRef]

92. Prasad, C.; Yuvaraja, G.; Venkateswarlu, P. Biogenic synthesis of $\mathrm{Fe}_{3} \mathrm{O}_{4}$ magnetic nanoparticles using Pisum sativum peels extract and its effect on magnetic and Methyl orange dye degradation studies. J. Magn. Magn. Mater. 2017, 424, 376-381. [CrossRef]

93. Kumar, B.; Smita, K.; Galeas, S.; Sharma, V.; Guerrero, V.H.; Debut, A.; Cumbal, L. Characterization and application of biosynthesized iron oxide nanoparticles using Citrus paradisi peel: A sustainable approach, Inorganic Chemistry Communications. Inorg. Chem. Commun. 2020, 119, 108116. [CrossRef]

94. Alshehri, A.; Malik, M.A.; Khan, Z.; Al-Thabaitia, S.A.; Hasan, N. Biofabrication of Fe nanoparticles in aqueous extract of Hibiscus sabdariffa with enhanced photocatalytic activities. RSC Adv. 2017, 7, 25149-25159. [CrossRef]

95. Vasantharaj, S.; Sathiyavimal, S.; Senthilkumar, P.; LewisOscar, F.; Pugazhendh, A. Biosynthesis of iron oxide nanoparticles using leaf extract of Ruellia tuberosa: Antimicrobial properties and their applications in photocatalytic degradation. J. Photochem. Photobiol. B Biol. 2019, 192, 74-82. [CrossRef] [PubMed]

96. Kumar, B.; Smita, K.; Galeas, S.; Guerrero, V.H.; Debut, A.; Cumbal, L. One-Pot Biosynthesis of Maghemite $\left(\gamma-\mathrm{Fe}_{2} \mathrm{O}_{3}\right) \mathrm{Nanoparti-}$ cles in Aqueous Extract of Ficus carica Fruit and Their Application for Antioxidant and 4-Nitrophenol Reduction. Waste Biomass Valor. 2021, 12, 3575-3587. [CrossRef]

97. Adam, R.E.; Pozina, G.; Willander, M.; Nur, O. Synthesis of ZnO nanoparticles by co-precipitation method for solar driven photodegradation of Congo red dye at different pH. Photon. Nanostruct. Fundam. Appl. 2018, 32, 11-18. [CrossRef]

98. Kamat, P.V. Photochemistry on nonreactive and reactive (semiconductor) surfaces. Chem. Rev. 1993, 93, 267-300. [CrossRef]

99. Mudhoo, A.; Paliya, S.; Goswami, P.; Singh, M.; Lofrano, G.; Carotenuto, M.; Carraturo, F.; Libralato, G.; Guida, M.; Usman, M.; et al. Fabrication, functionalization and performance of doped photocatalysts for dye degradation and mineralization: A review. Environ. Chem. Lett. 2020, 18, 1825-1903. [CrossRef]

100. Zhu, X.; Qiu, F.; Li, X.; Rong, X.; Wang, J.; Yang, D. Silver carbonateloaded on activated carbon composite photocatalyst with enhanced photocatalytic activity under visible light irradiation. Mater. Technol. 2017, 32, 38-45. [CrossRef]

101. Bhattacharjee, A.; Ahmaruzzaman, M. A novel and green process for the production of $\mathrm{SnO}_{2}$ quantum dots and its application as a photocatalyst for the degradation of dyes from aqueous phase. J. Colloid Interface Sci. 2015, 448, 130-139. [CrossRef]

102. Colvin, V.L. The potential environmental impact of engineered nanomaterials. Nat. Biotechnol. 2003, 21, 1166-1170. [CrossRef]

103. Syafiuddin, A.; Salim, M.R.; Beng Hong Kueh, A.; Hadibarata, T.; Nur, H. A Review of Silver Nanoparticles: Research Trends, Global Consumption, Synthesis, Properties, and Future Challenges. J. Chin. Chem. Soc. 2017, 64, 732-756. [CrossRef]

104. Wang, L.; Zhang, T.; Li, P.; Huang, W.; Tang, J.; Wang, P.; Liu, J.; Yuan, Q.; Bai, R.; Li, B.; et al. Use of Synchrotron RadiationAnalytical Techniques To Reveal Chemical Origin of Silver-Nanoparticle Cytotoxicity. ACS Nano. 2015, 9, 6532-6547. [CrossRef] [PubMed]

105. Takenaka, S.; Karg, E.; Roth, C.; Schulz, H.; Ziesenis, A.; Heinzmann, U.; Schramel, P.; Heyder, J. Pulmonary and systemic distribution of inhaled ultrafine silver particles in rats. Environ. Health Perspect. 2001, 109, 547-549. [PubMed]

106. Braydich-Stolle, L.; Hussain, S.; Schlager, J.; Hofmann, M.C. In Vitro Cytotoxicity of Nanoparticles in Mammalian Germline Stem Cells. Toxicol. Sci. 2005, 88, 412-419. [CrossRef] 
107. Kim, Y.S.; Kim, J.S.; Cho, H.S.; Rha, D.S.; Kim, J.M.; Park, J.D.; Choi, B.S.; Lim, R.; Chang, H.K.; Chung, Y.H.; et al. Twenty-eightday oral toxicity, genotoxicity, and gender-related tissue distribution of silver nanoparticles in Sprague-Dawley rats. Inhal. Toxicol. 2008, 20, 575-583. [CrossRef]

108. Goodman, C.M.; McCusker, C.D.; Yilmaz, T.; Rotello, V.M. Toxicity of gold nanoparticles functionalized with cationic and anionic side chains. Bioconj. Chem. 2004, 15, 897-900. [CrossRef]

109. Pan, Y.; Neuss, S.; Leifert, A.; Fischler, M.; Wen, F.; Simon, U.; Schmid, G.; Brandau, W.; Jahnen-Dechent, W. Size-Dependent Cytotoxicity of Gold Nanoparticles. Small 2007, 3, 1941-1949. [CrossRef]

110. Valdiglesias, V.; Fernández-Bertólez, N.; Kilic, G.; Costa, C.; Costa, S.; Fraga, S.; Bessa, M.J.; Pásaro, E.; Teixeira, J.P.; Laffon, B. Are iron oxide nanoparticles safe? Current knowledge and future perspectives. J. Trace Elem. Med. Biol. 2016, 38, 53-63. [CrossRef]

111. Wang, B.; Yin, J.-J.; Zhou, X.; Kurash, I.; Chai, Z.; Zhao, Y.; Feng, W. Physicochemical origin for free radical generation of iron oxide nanoparticles in biomicroenvironment: Catalytic activities mediated by surface chemical states. J. Phys. Chem. C 2012, 117, 383-392. [CrossRef] 